\title{
Cobalt-free $\operatorname{SrNb}_{\mathrm{x}} \mathrm{Fe}_{1-\mathrm{x}} \mathrm{O}_{3-\delta}(\mathrm{x}=0.05,0.1$ and 0.2$)$ perovskite
}

\section{cathodes for intermediate temperature solid oxide fuel cells}

ShanshanJiang ${ }^{a}$, Jaka Sunarso $^{b}$, Wei Zhou ${ }^{*, a}$, Jian Shen $^{a}$, Ran Ran $^{*, a}$, Zongping Shao $^{a}$

${ }^{a}$ State Key Laboratory of Materials-Oriented Chemical Engineering, College of Chemistry \& Chemical Engineering, Nanjing Tech University, No. 5 Xin Mofan Road, Nanjing 210009, People's Republic of China E-mail: (R. Ran) ranr@njut.edu.cn; (W. Zhou) zhouwei1982@njtech.edu.cn; Fax: +86-25-83172256

${ }^{b}$ Department of Chemistry, University of Waterloo, 200 University Avenue West, Waterloo, Ontario N2L 3G1, Canada

Keywords: cathode, cobalt-free, doped $\mathrm{SrFeO}_{3-\delta}$, oxygen vacancy, solid oxide fuel cells 


\section{Abstract}

The development of high performance perovskite cathode for solid oxide fuel cells (SOFCs) relies upon the knowledge and understanding of the interplay between the metal oxide components, structure, redox properties and conductivity. In this work, we partially substituted $\mathrm{Fe}$ on $\mathrm{SrFeO}_{3-\delta}$ with $\mathrm{Nb}$. In particular, $3 \mathrm{Nb}$-doped compositions were prepared, e.g. $\mathrm{SrNb}_{0.05} \mathrm{Fe}_{0.95} \mathrm{O}_{3-\delta}$ (SNF0.05), $\mathrm{SrNb}_{0.1} \mathrm{Fe}_{0.9} \mathrm{O}_{3-\delta}$ (SNF0.1) and $\mathrm{SrNb}_{0.2} \mathrm{Fe}_{0.8} \mathrm{O}_{3-\delta}(\mathrm{SNF} 0.2)$. Mössbauer spectroscopy revealed decreasing ratio of $\mathrm{Fe}^{4+}$ to $\mathrm{Fe}^{3+}$ at the higher $\mathrm{Nb}$ doping content which translates to the gradual decrease of the average $\mathrm{Fe}$ oxidation state from 3.403 (for SNF0.05) to 3.375 (for SNF0.1) and to 3.291 (for SNF0.2). Likewise, the oxygen desorption process and the thermal expansion coefficients decreased with increasing $\mathrm{Nb}$ content, therefore providing evidence on their correlation with the thermal reduction of $\mathrm{Fe}^{4+}$. The temperature-dependent oxygen nonstoichiometry displayed two different regimes separated by a transition temperature of $625^{\circ} \mathrm{C}$, below which SNF0.2 showed the highest nonstoichiometry and above which SNF0.05 provided the highest nonstoichiometry. The analogous shifting in trends was reproduced for oxygen reduction reaction (ORR) performance which signifies oxygen nonstoichiometry as the main variable affecting ORR performance. 


\section{Introduction}

Solid oxide fuel cells (SOFCs) demonstrate potential as one of the clean energy technology plat forms given their high energy efficiency, low emission and fuel flexibility[1-3].The market expansion of this technology has been largely hindered by the high operating temperature $\left(>800^{\circ} \mathrm{C}\right)$ which brings practical issues such as high temperature sealing and reactions between the cell components. During the past decades, advances have been garnered to reduce the operation temperature of SOFC into the intermediate range $\left(600-800{ }^{\circ} \mathrm{C}\right)$ [4-7]. As the temperature is lowered, the polarization resistance increased which results in the diminished oxygen ions diffusion and oxygen reduction reaction (ORR) activity on the cathode side [8]. Therefore, cathode becomes the limiting component towards SOFC performance.

Cobalt-containing perovskite oxides normally exhibit mixed ionic-electronic conducting (MIEC) properties. Unlike in classical, electronic conductor cathode where the ORR is confined to triple phase boundary (TPB) area only, ORR in MIEC cathode occurs along its entire surface [9-14]. It is this attribute that partly explains their remarkable ORR performance at lower temperatures $\left(<800^{\circ} \mathrm{C}\right)$. During heating however, as the oxygen vacancies are formed in their lattices, strong reduction of cobalt takes place to compensate these oxygen losses which then manifests into significant lattice expansion [15-18]. In addition, high cost and compatibility issues with electrolyte were also claimed as the other drawbacks of cobalt-based perovskite cathodes [19-23]. 
Iron-based perovskite oxides such as those based on $\mathrm{SrFeO}_{3-\delta}$ is an enticing alternative in view of their moderate redox behavior and a relatively low iron price [24, 25]. In our previous work, we reported higher ORR activity for Bi-doped $\mathrm{SrFeO}_{3-\delta}$ relative to La-doped $\mathrm{SrFeO}_{3-\delta}$ as a consequence of higher polarizable property of $\mathrm{Bi}$ ion [26-30]. More recently; we characterized $\mathrm{SrNb}_{0.1} \mathrm{Fe}_{0.9} \mathrm{O}_{3-\delta}(\mathrm{SNF} 0.1)$ as a cathode for SOFCs. This cathode, when combined with $8 \%$ yttria-stabilized zirconia (YSZ) electrolyte and samarium doped ceria $\left(\mathrm{Sm}_{0.2} \mathrm{Ce}_{0.8} \mathrm{O}_{1.9}, \quad \mathrm{SDC}\right)$ electrolyte displayed power density of $1403 \mathrm{mWcm}^{-2}$ at $800{ }^{\circ} \mathrm{C}$ and $919 \mathrm{mWcm}^{-2}$ at $600{ }^{\circ} \mathrm{C}$, respectively $[31,32]$. A more systematic study on the compositional doping of this $\mathrm{Nb}$-doped $\mathrm{SrFeO}_{3-\delta}$ perovskite oxide, e.g. $\mathrm{SrNb}_{\mathrm{x}} \mathrm{Fe}_{1-\mathrm{x}} \mathrm{O}_{3-\delta}$ is yet to be followed-up.

Despite numerous reports on cobalt-free cathodes for SOFCs, the mechanism behind the high activity of $\mathrm{SrFeO}_{3-\delta}$-family is of great importance for designing new materials with functional properties and basic understanding of the materials science. Here, we studied the ORR activity of $\mathrm{SrNb}_{\mathrm{x}} \mathrm{Fe}_{1-\mathrm{x}} \mathrm{O}_{3-\delta}(\mathrm{x}=0.05,0.1$ and 0.2$)$. The oxygen nonstoichiometry and valence state of Fe were probed and correlated with the ORR performance. We also evaluated their thermal expansion behavior, morphologies and electrical conductivities.

\section{Experimental}

\subsection{Powder synthesis}

$\mathrm{SrNb}_{\mathrm{x}} \mathrm{Fe}_{1-\mathrm{x}} \mathrm{O}_{3-\delta}$ (denoted as $\mathrm{SNFx}, \mathrm{x}=0.05,0.1$ and 0.2 ) powders were synthesized 
by solid-state route using planetary milling. Stoichiometric amounts of $\mathrm{SrCO}_{3}, \mathrm{Nb}_{2} \mathrm{O}_{5}$ and $\mathrm{Fe}_{2} \mathrm{O}_{3}$ (all of analytical grade, from Sinopharm Chemical Reagent Co. Ltd.) were weighed before mixing and completely milling inside a FRITSCH Pulverisette 6. Alcohol was used as a solvent and the milling was performed at a rotation speed of $400 \mathrm{rpm}$ for $0.5 \mathrm{~h}$. After evaporating the solvent at $100{ }^{\circ} \mathrm{C}$, the powder was calcined at $1250{ }^{\circ} \mathrm{C}$ in air for $20 \mathrm{~h}$ and then ground using mortar and pestle for $0.5 \mathrm{~h}$. The milling and calcination were performed twice to obtain highly pure SNFx powders.

\subsection{Preparation of symmetrical and single fuel cells}

Symmetrical cells with $\mathrm{SNFx} \mid \mathrm{Sm}_{0.2} \mathrm{Ce}_{0.8} \mathrm{O}_{1.9}$ (SDC)|SNFx configuration were fabricated for electrochemical impedance spectroscopy (EIS) measurements. The suitable amount of the SDC powder was weighed and pressed into pellet using a stainless steel die under a hydraulic pressure under of $10 \mathrm{MPa}$ and sintering at $1400{ }^{\circ} \mathrm{C}$ for half an hour to obtain the dense electrolyte layer. $\mathrm{SrNb}_{\mathrm{x}} \mathrm{Fe}_{1-\mathrm{x}} \mathrm{O}_{3-\delta}(\mathrm{SNFx})$ slurries were prepared by dispersing SNFx powders into pre-mixed solutions of glycerol, ethylene glycol and isopropyl alcohol followed by mixing and milling of the mixtures within Pulverisette 6, FRITSCH at $400 \mathrm{rpm}$ for $0.5 \mathrm{~h}$. The symmetrical cell was prepared by spraying SNFx slurries onto opposing surfaces of SDC disks ( $13 \mathrm{~mm}$ in diameter, $\sim 1 \mathrm{~mm}$ in thickness) followed by calcination at $1000^{\circ} \mathrm{C}$ for $2 \mathrm{~h}$ in air.

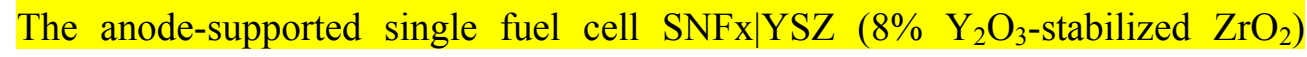
|YSZ-Ni (50:50 vol \%) was fabricated for the fuel cell performance test. The YSZ-Ni (50:50 vol \%) anode substrate was prepared via a tape casting process, and the 
thin-film YSZ electrolyte was painted on one side of the as-prepared anode followed by co-sintering at $1350{ }^{\circ} \mathrm{C} 5 \mathrm{~h}$ in air. The cathode slurry was subsequently sprayed onto the central surface of the sintered electrolyte and calcined at $900{ }^{\circ} \mathrm{C} 2 \mathrm{~h}$ in air.

\subsection{Characterization}

The crystal structures of SNFx powders were determined using powder X-ray diffraction (XRD, Bruker AXS D8 Advance) with filtered $\mathrm{Cu}-\mathrm{K} \alpha$ radiation at $40 \mathrm{kV}$ and $40 \mathrm{~mA}$ and a receiving slit of $0.2-0.4 \mathrm{~mm}$. The experimental diffraction patterns were collected at room temperature by stepwise scanning in the range of $20^{\circ} \leq 2 \theta \leq 90^{\circ}$ with a scan rate of $2^{\circ} \mathrm{min}^{-1}$. Reitveld refinement on the XRD patterns was conducted using DIFFRAC ${ }^{\text {plus }}$ Topas 4.2 software.

The concentration of the metal ions ( $\mathrm{Sr}, \mathrm{Nb}$ and $\mathrm{Fe}$ ) was analyzed by inductively coupled plasma-optical emission spectrometer (ICP-OES) on Optima 7000DV ICP-OES (PerkinElmer). The powders were dissolved in a mixture consisting of 30 $\mathrm{mL}$ nitric acid, $10 \mathrm{~mL}$ hydrochloric acid and $1 \mathrm{~mL}$ hydrofluoric acid. The suspension was transferred to $90-\mathrm{ml}$ Teflon-lined stainless autoclaves, and then hydrothermal treatment was conducted at $80{ }^{\circ} \mathrm{C}$ for $2 \mathrm{~h}$. The solution was diluted to $1 \mathrm{~L}$ with deionized water before the ICP measurement.

Oxygen temperature programmed desorption $\left(\mathrm{O}_{2}-\mathrm{TPD}\right)$ was performed to detect the reduction properties of transition metal, e.g. iron within the perovskite oxide. For $\mathrm{O}_{2}$-TPD analysis, approximately 100mg of SNFx powders (with particle size of 40-60 meshes) were loaded into a quartz tube. The tube was then placed in a tubular furnace 
equipped with a temperature controller. Argon was used as the carrier gas at a flow rate of $20 \mathrm{~mL}(\mathrm{STP}) \mathrm{min}^{-1}$. The temperature was increased from 50 to $900{ }^{\circ} \mathrm{C}$ at a ramp rate of $10{ }^{\circ} \mathrm{C} \min ^{-1}$. The effluent gases were passed into a mass spectrometer (MS Hiden QIC-20) for oxygen concentration analysis.

Mössbauer spectroscopy was used to probe the oxidation states of iron in SNFx powders. Transmission Mössbauer spectra of SNFx powders were recorded using a conventional constant acceleration spectrometer with a $\gamma$-ray source of $25 \mathrm{mCi} 57 \mathrm{Co}$ in a palladium matrix moving at room temperature. The absorber was kept static in a temperature-controllable cryostat. All isomer shifts were quoted with respect to $\alpha$-Fe at room temperature. The Mössbauer spectrum was fitted using the MOSSWINN 3.0 program. The room temperature average valence states of iron and oxygen nonstoichiometry of SNFx powders were calculated using Mössbauer spectroscopy parameters.

The room temperature oxygen nonstoichiometry of SNFx was also tested by iodometric titration. For room-temperature oxygen nonstoichiometry evaluation, approximately $0.1 \mathrm{~g}$ of SNFx powder was dissolved in a $6.0 \mathrm{~mol} \mathrm{~L}^{-1} \mathrm{HCl}$ solution under an argon atmosphere (to prevent the oxidation of $\mathrm{I}^{-}$ions in air) before titration by thiosulfate $\left(\mathrm{S}_{2} \mathrm{O}_{3}{ }^{2-}\right)$ solution. Several drops of starch solutions were added as an indicator to facilitate color change from the initially orange transparent solution to yellow.

The high temperature oxygen nonstoichiometry and average valence of Fe were measured using thermal gravimetric analysis (TGA). The TGA of SNFx powder was 
performed in a DTA/TA (NETZSH, STA 449 F3) using synthetic air between room temperature and $1050{ }^{\circ} \mathrm{C}$. The oxygen nonstoichiometry of SNFx powders at different temperature was calculated using TGA data. The oxygen nonstoichiometry as a function of the temperature in the sample was obtained using equation (1):

$$
\delta=\frac{M \times m_{o}-\left(M-15.9994 \times \delta_{o}\right) \times m}{15.9994 \times m_{o}}
$$

Where $\mathrm{m}_{\mathrm{o}}$ and $\mathrm{m}$ is the initial weight and the weight at a certain temperature during heating, respectively; $\mathrm{M}$ is the molar mass of the stoichiometric SNFx; $\delta_{0}$ is the oxygen nonstoichiometry at room temperature calculated using Mössbauer spectroscopy parameters.

For thermal expansion coefficient tests, sintered disks were previously prepared. The thermal expansion data were collected using Netzsch DIL 402C/3/G dilatometer in air from room temperature to $1000^{\circ} \mathrm{C}$ with a ramping rate of $5^{\circ} \mathrm{C} \mathrm{min}^{-1}$.

The morphology of the symmetric cell was probed using a field emission scanning electron microscope (FE-SEM, JEOL-S4800).

For the electrical conductivity test, the SNFx powders were palletized into rectangular bars of the dimension $2 \mathrm{~mm} \times 5 \mathrm{~mm} \times 20 \mathrm{~mm}$, and then sintered at $1200{ }^{\circ} \mathrm{C}$ for $5 \mathrm{~h}$ in the ambient atmosphere. The densities of bars we used for the test was over $93 \%$ under the theoretical values. Electrical conductivity was measured via the four-terminal DC technique. The current and the voltage were detected by Keithley 2420 source meter at an interval of $25^{\circ} \mathrm{C}$ within temperature range of $300-900{ }^{\circ} \mathrm{C}$ under air. 
The electrochemical impedance spectra (EIS) of the cathodes were measured using an electrochemical workstation (Solartron 1260A frequency response analyzer and a Solartron 1287 potentiostat) within a temperature range of $550-750{ }^{\circ} \mathrm{C}$ at an interval of $50{ }^{\circ} \mathrm{C}$ in ambient air. The applied frequency ranged from $0.01 \mathrm{~Hz}$ to100 $\mathrm{kHz}$ and the signal amplitude was $10 \mathrm{mV}$ under open circuit voltage condition. Data from the impedance spectra were analyzed using Z-plot 3.0c software.

To test the performance of the single fuel cell, the cell was sealed onto the top of a quartz tube reactor with silver paste and fixed inside the furnace. High-purity $\mathrm{H}_{2}$ was fed into the anode chamber as fuel at a flow rate of $80 \mathrm{~mL} \mathrm{~min}^{-1}(\mathrm{STP})$, and the cathode was exposed to ambient air. A Keithley 2420 Source Meter with a four-probe configuration was used for $I-V$ and $I-P$ polarization tests under the approximate temperature range of $550-700{ }^{\circ} \mathrm{C}$. The power density was calculated based on the active area of the cathode, which was approximately $0.48 \mathrm{~cm}^{2}$.

\section{Results and discussion}

The SNFx solid precursors were calcined at $1250^{\circ} \mathrm{C}$ for $20 \mathrm{~h}$ in air and the calcination repeated once to ensure the synthesis of the highly pure SNFx powders. In order to identify the composition of the synthesized samples, we deployed ICP-OES technique.

Table 1 shows the concentration of strontium, niobium and iron ions for the SNFx $(\mathrm{x}=0.05,0.1,0.2)$ powders. The derived molar ration of the metal irons is 1.0: 0.048 : 0.95, 1.0: $0.099: 0.90$ and 1.0: $0.20: 0.80$ for the SNF0.05, SNF0.1 and SNF0.2, 
respectively, which match well with the target values.

The room temperature powder X-ray diffraction (XRD) patterns of SNFx oxides calcined at $1250{ }^{\circ} \mathrm{C}$ are depicted in Figure 1a. All three compositions, e.g. SNF0.05, SNF0.1 and SNF0.2 $\left(\mathrm{SrNb}_{0.05} \mathrm{Fe}_{0.95} \mathrm{O}_{3-\delta}, \quad \mathrm{SrNb}_{0.1} \mathrm{Fe}_{0.9} \mathrm{O}_{3-\delta}\right.$ and $\mathrm{SrNb}_{0.2} \mathrm{Fe}_{0.8} \mathrm{O}_{3-\delta}$, respectively) exhibited single phase without formation of any impurities. A closer look into the patterns revealed the shifting of the peaks positions into lower angles with increasing $\mathrm{Nb}^{5+}$ content. Figure $1 \mathbf{b}$ captured this observation around $2 \theta=33^{\circ}$ for

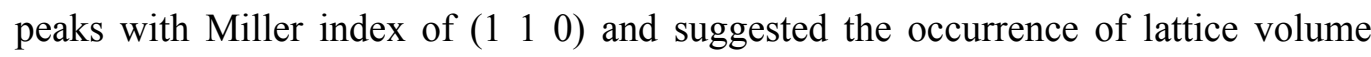
expansion. To identify the space group and cell parameters, we performed the Reitveld refinement on the XRD pattern of the samples and the refined structural parameters are listed in Table 2. At the room temperature, the SNF0.05, SNF0.1, SNF0.2 exhibited primitive lattice in $\mathrm{Pm} 3 \mathrm{~m}, \mathrm{P} 4 \mathrm{~mm}$ and $\mathrm{P} 4 \mathrm{~mm}$ space group, respectively. The volume of the unit cell was expanded with increasing the concentration of niobium doping, because ionic radius of $\mathrm{Nb}^{5+}(0.70 \AA)$ is larger relative to $\mathrm{Fe}^{4+}(0.645 \AA) / \mathrm{Fe}^{3+}(0.585 \AA)$ cations in octahedral coordination [33].

We noticed the leaching out of white-colored $\mathrm{Nb}_{2} \mathrm{O}_{5}$ particles during the acid-assisted dissolution of SNFx powders (required for iodometric titration tests) which rendered the determination of the average Fe oxidation state using this method unreliable. As an alternative, we chose to determine the oxidation state of Fe via Mössbauer spectroscopy. Mössbauer spectra of SNFx collected at room temperature (Figure 2) could be resolved into a singlet featuring an isomer shift between -0.126 
and $-0.191 \mathrm{~mm} \mathrm{~s}^{-1}$ and a doublet featuring an isomer shift between 0.324 and 0.350 $\mathrm{mm} \mathrm{s}^{-1}$ and a quadrupole splitting between 0.411 and $0.465 \mathrm{~mm} \mathrm{~s}^{-1}$. While the former was attributed to $\mathrm{Fe}^{4+}$, the latter had the characteristics of $\mathrm{Fe}^{3+}$ cations. From the fitting results, the ratio of the peak area of the singlet and the doublet was calculated and used to obtain the proportion of $\mathrm{Fe}^{4+}$ to $\mathrm{Fe}^{3+}$ for each composition (Table 3). The trend indicated an increased amount of $\mathrm{Fe}^{3+}$ with increasing $\mathrm{Nb}^{5+}$ content. This translates to lower average $\mathrm{Fe}$ oxidation state (e.g. $\mathrm{n}$ in $\mathrm{Fe}^{\mathrm{n}+}$ ) and reduced oxygen nonstoichiometry $(\delta)$, as summarized in Table 4 . The decreased amount of $\mathrm{Fe}^{4+}$ with increasing $\mathrm{Nb}^{5+}$ content, in particular, explains the lattice volume expansion noted earlier (Figure 1b). Consistent with the charge neutrality criterion, the addition of $\mathrm{Nb}$ ions with high oxidation state in SNFx was compensated through the lowering of the oxidation state of the residual transition metal $(\mathrm{Fe})$.

Figure 3a displays the thermal expansion behavior of SNFx from dilatometry experiments performed by heating from room temperature to $1000^{\circ} \mathrm{C}$. The calculated thermal expansion coefficients (TECs) for three different temperature ranges are listed in Table 5. The average TECs for SNFx between room temperature and $1000{ }^{\circ} \mathrm{C}$ are $27.6 \times 10^{-6}, 22.1 \times 10^{-6}$ and $21.7 \times 10^{-6} \mathrm{~K}^{-1}$ for $\mathrm{x}=0.05,0.1,0.2$, respectively. Higher $\mathrm{Nb}$ content correlates with lower TEC value, in accord with the lower amount of $\mathrm{Fe}^{4+}$ available for thermal reduction process. The inflection points on the plot of $\Delta \mathrm{L} / \mathrm{L}_{\mathrm{o}}$ versus temperature (Figure 3a) are present at $\sim 400{ }^{\circ} \mathrm{C}$ and are mostly associated with the onset of $\mathrm{Fe}^{4+}$ reduction. Slight discrepancy on the onset temperatures detected by $\mathrm{O}_{2}$-TPD and dilatometry originates from the different oxygen partial pressure applied 
in these two experiments. We also noted, upon closer look on Figure 3a, that the inflection point moves slightly to lower temperature for higher doping content compositions, i.e. from $\sim 410{ }^{\circ} \mathrm{C}$ for $\mathrm{x}=0.05$ to $380{ }^{\circ} \mathrm{C}$ for $\mathrm{x}=0.2$ which suggests enhanced thermal reducibility for iron cations at higher $\mathrm{Nb}$ doping amount. $\mathrm{O}_{2}$-temperature programmed desorption (TPD) equipped with mass spectrometer was used further to assess the thermal release of oxygen gas from the perovskite lattice, normally accompanied by simultaneous reduction of the B-site cations. The onset temperature of oxygen desorption for SNFx powders was $\sim 350{ }^{\circ} \mathrm{C}$ (Figure 3b), above which the reduction of $\mathrm{Fe}^{4+}$ to $\mathrm{Fe}^{3+}$ occurred (Assuming that $\mathrm{Nb}^{5+}$ was not reducible). Here, the area of the oxygen desorption peak is indicative of the extent of the reduction process which in turn depends upon the amount of $\mathrm{Fe}^{4+}$ ions available to be reduced. The decreasing peak area with increasing $\mathrm{x}$ from 0.05 to 0.2 finds excellent agreement with the data shown on $\mathrm{Fe}^{4+} / \mathrm{Fe}^{3+}$ proportion (Table 3).

The average valence states of Fe (on SNFx) and the oxygen nonstoichiometry of SNFx between 500 and $750{ }^{\circ} \mathrm{C}$ were acquired from thermal gravimetric analysis (TGA) and previously listed room temperature $n$ and $\delta$ values (Table 4). The temperature range matches the temperature range used for the cathode oxygen reduction reaction (ORR) activity tests. The existence of crossover temperature of $625^{\circ} \mathrm{C}$ is indicated in Figure 4a, where above and below this temperature, different trends of oxygen nonstoichiometry (as a function of $\mathrm{x}$ ) prevail. Below $625^{\circ} \mathrm{C}$, SNF0.05 exhibited the lowest nonstoichiometry. This lowest value was surpassed incrementally by SNF0.1 and SNF0.2. Rapid increase of the nonstoichiometry for 
SNF0.05 reversed this trend beyond $625{ }^{\circ} \mathrm{C}$. The temperature dependent average valence states of Fe (Figure 4b), on the other hand, highlights continuous decrease of values with increasing temperature. Such progressive decline led to analogous overall trend, e.g. the lowering of the valence state of Fe in the order of SNF0.05, SNF0.1 and SNF0.2.

The ORR activity of SNFx cathodes was quantified by electrochemical impedance spectroscopy (EIS) of symmetrical cells using SDC electrolyte between 550 and $750{ }^{\circ} \mathrm{C}$. The Arrhenius plots of the area specific resistances (ASRs) and the activation energies $\left(E_{a}\right)$ of SNFx cathodes are displayed in Figure 5. The ORR plots imitate the results for the oxygen nonstoichiometry in an opposite manner (Figure 4a), where for the composition having the highest oxygen nonstoichiometry, the highest ORR activity (reflected by the lowest ASR value) is found and vice versa (Note the reversed values on the temperature scale when comparing Figure 4 and Figure 5). This suggests correlation between oxygen nonstoichiometry and ORR activity with larger nonstoichiometry favored higher ORR activity. To confirm this deduction, we further checked the possible morphological (or geometrical) contribution from the porous cathodes using scanning electron microscope; the results of which are shown in Figure 6. The image captured well-defined interface between cathode and electrolyte and more importantly, quite analogous grain and pore sizes for the three SNFx cathodes. As such, the ORR enhancements could not be attributed to the geometrical effect.

In addition, we tested the electrical conductivity of SNFx. With increasing $\mathrm{Nb}$ doping level, the conductivity decreases (Figure 7) presumably due to the blocking 
effect of $\mathrm{Nb}^{5+}$ towards the electronic conductivity. The relationship between the conductivity and ORR activity is not clear based on the EIS results. Given ORR activity of the cathodes was tested by EIS under a negligible current biases $(<10 \mathrm{~mA}$ $\mathrm{cm}^{-2}$ ), the effect of electronic conductivity on ORR could be overlooked based on EIS. Therefore, the single fuel cells were tested to evaluate the cathode performance under polarization conditions. The electrochemical performance of the $\mathrm{SrFeO}_{3-\delta}$ and $\mathrm{SNFx}$ cathodes were tested on YSZ-Ni (50: 50 vol\%) anode-supported YSZ electrolyte single cell. Figures 8a-d shows the I-V and I-P curves of the single SOFCs recorded from 550 to $700{ }^{\circ} \mathrm{C}$. The open-circuit voltages (OCVs) are all over $1.11 \mathrm{~V}$, indicating the good integrity and sealing of the fuel cells. The peak power densities of all the cells at various temperatures are summarized in Figure 8e. As expected, the fuel cell with the $\mathrm{SrFeO}_{3-\delta}$ cathode delivers the lowest power densities compared to those with the SNFx cathodes. The peak power densities of fuel cells with the SNF0.05, SNF0.1 and SNF0.2 cathodes are 710,810 and $650 \mathrm{~mW} \mathrm{~cm}^{-2}$ at $700{ }^{\circ} \mathrm{C}$, respectively, surpassing the requirements of $500 \mathrm{mWcm}^{-2}$ for practical use of a single cell. However, the trend of power generation for the SNFx based fuel cells is not consistent with that observed for the ORR for SNFx shown in Figure 5. The power densities of the SNF0.05 and SNF0.1 based cells are similar with each other, which are higher than those of the SNF0.2 based cell in the temperature range studied. As observed in Figure 5, however, the ORR activity of the SNF0.2 is higher than those of other two materials at temperature below $650{ }^{\circ} \mathrm{C}$. The inconsistency is likely stemmed from the lowered conductivity of SNF0.2. To this end, the electrical conductivity of SNFx 
needs to be optimized to further improve the power generation of the fuel cells.

$\mathrm{Nb}$ acted as a donor dopant for $\mathrm{SrFeO}_{3-\delta}$. The resultant defect compensation effect can be explained using the following reaction (equation (2)).

$$
\mathrm{Nb}_{2} \mathrm{O}_{5}+2 \mathrm{SrO}+2 \mathrm{~V}_{o}^{\bullet \bullet}=2 \mathrm{Sr}_{\mathrm{Sr}}+2 \mathrm{Nb}_{\mathrm{Fe}}^{\bullet \bullet}+7 \mathrm{O}_{o}^{\times}
$$

$\mathrm{Nb}$ addition may result in the decrease of oxygen vacancies and/or $\mathrm{Fe}^{4+}$. Our room temperature oxygen nonstoichiometry values supported the defect compensation mechanism through the reduction of oxygen vacancies. We speculate that $\mathrm{Nb}$ doping also facilitated $\mathrm{Fe}^{4+}$ reduction given the lowering of onset temperature for $\mathrm{Fe}^{4+}$ reduction (Figure 3b) as well as the reduction of the activation energy of oxygen vacancies formation (Figure 4a) and ORR (Figure 5) for higher Nb-containing compositions. Hou et al. [34] reported the partial substitution (doping) of 10 mole $\%$ $\mathrm{Fe}$ in $\mathrm{SrFeO}_{3-\delta}$ with $\mathrm{K}$ which led to optimized $\mathrm{Fe}^{4+}$ to $\mathrm{Fe}^{3+}$ ratio and an average oxidation state of 3.7 . With such adjustment, adequate ionic conductivity at $800{ }^{\circ} \mathrm{C}$, in addition to high electronic conductivity (from untilting $\mathrm{FeO}_{6}$ octahedra in tetragonal perovskite) was obtained. In this work, nonetheless, the average valence states of Fe decreased with increased $\mathrm{Nb}$ doping amount and the electronic conductivity was traded off with the oxygen nonstoichiometry. It is worthwhile to note that the positive correlation between oxygen nonstoichiometry and ORR activity observed here in conjunction with less dominant role of $\mathrm{Fe}^{4+} / \mathrm{Fe}^{3+}$ coupleis in agreement with several other works [35-40].

\section{Conclusions}

In this work, we evaluated the physicochemical properties of a series of $\mathrm{Nb}$-doped $\mathrm{SrFeO}_{3-\delta}(\mathrm{SNFx})$ perovskite oxides, e.g. $\mathrm{SrNb}_{0.05} \mathrm{Fe}_{0.95} \mathrm{O}_{3-\delta}(\mathrm{SNF} 0.05), \mathrm{SrNb}_{0.1} \mathrm{Fe}_{0.9} \mathrm{O}_{3-\delta}$ 
(SNF0.1) and $\mathrm{SrNb}_{0.2} \mathrm{Fe}_{0.8} \mathrm{O}_{3-\delta}$ (SNF0.2) for application as cathode in solid oxide fuel cells. Room temperature Mössbauer spectroscopy showed decreasing ratio of $\mathrm{Fe}^{4+}$ to $\mathrm{Fe}^{3+}$ and equivalently lower $\mathrm{Fe}$ oxidation state for higher $\mathrm{Nb}$-containing compositions. Likewise, this trend correlates with the lowering of the thermal reduction process and the thermal expansion coefficients with increasing $\mathrm{Nb}$ content. The oxygen reduction reaction (ORR) activity of SNFx follows the oxygen nonstoichiometry trend with the presence of the transition temperature at $625^{\circ} \mathrm{C}$. Below $625^{\circ} \mathrm{C}, \mathrm{SNF} 0.2$ provided the highest ORR activity while above $625{ }^{\circ} \mathrm{C}$; SNF0.05 achieved the highest ORR activity. Further tests on the morphology and the electrical conductivity provided less compelling evidence of their contributions towards the ORR activity. The low electrical conductivity of SNFx may impede their practical use under operating conditions. Further optimization of the SNFx cathodes can be achieved by improving their electrical conductivity.

\section{Acknowledgments}

This work was financially supported by the Key Projects in Nature Science Foundation of Jiangsu Province under contract No.BK2011030, by the National Science Foundation for Distinguished Young Scholars of China under contract No. 51025209, by the Priority Academic Program Development of Jiangsu Higher Education Institutions and the Program for Jiangsu Specially-Appointed Professors.

\section{Reference}


[1] B.C. Steele, A. Heinzel, Materials for fuel-cell technologies, Nature 414 (2001)

$345-352$

[2] T. Hibino, A. Hashimoto, T. Inoue, J.I. Tokuno, S.I. Yoshida, M. Sano, A low-operating-temperature solid oxide fuel cell in hydrocarbon-air mixtures, Science 288 (2000) 2031-2033.

[3] N.Q. Minh, Ceramic fuel cells, J. Am. Ceram. Soc. 76 (1993) 563-588.

[4] W. Zhou, R. Ran, Z.P. Shao, Progress in understanding and development of $\mathrm{Ba}_{0.5} \mathrm{Sr}_{0.5} \mathrm{Co}_{0.8} \mathrm{Fe}_{0.2} \mathrm{O}_{3-\delta}$-based cathodes for intermediate-temperature solid-oxide fuel cells: a review, J. Power Sources, 192 (2009) 231-246.

[5] D.J.L. Brett, A. Atkinson, N.P. Brandon, S.J. Skinner, Intermediate temperature solid oxide fuel cells, Chem. Soc. Rev.37 (2008) 1568-1578.

[6]W. Zhou, Z.H. Zhu, The instability of solid oxide fuel cells in an intermediate temperature region, Asia-Pacific J. Chem. Eng.6 (2011) 199-203.

[7] E.D. Wachsman, K.T. Lee, Lowering the temperature of solid oxide fuel cells, Science 334 (2011) 935-939.

[8] W. Zhou, J. Sunarso, M.W. Zhao, F.L. Liang, T. Klande, A. Feldhoff, A Highly Active Perovskite Electrode for the Oxygen Reduction Reaction Below $600^{\circ} \mathrm{C}$, Angew. Chem. Int. Ed. 2013, 52, 14036-14040.

[9] F.L. Liang, W. Zhou, Z.H. Zhu, A Highly Stable and Active Hybrid Cathode for Low-Temperature Solid Oxide Fuel Cells, ChemElectroChem 1 (2014) 1627-1631.

[10] C.R. Xia, W. Rauch, F.L. Chen, M.L. Liu, $\mathrm{Sm}_{0.5} \mathrm{Sr}_{0.5} \mathrm{CoO}_{3}$ cathodes for low-temperature SOFCs， Solid State Ionics 149 (2002) 11-19. 
[11] W. Zhou, L. Ge, Z.G. Chen, F.L. Liang, H.Y. Xu, J. Motuzas, A. Julbe, Z.H. Zhu, Amorphous iron oxide decorated 3D heterostructured electrode for highly efficient oxygen reduction, Chem. Mater. 23 (2011) 4193-4198.

[12]J.H. Kim, Y. Kim, P.A. Connor, J.T.S. Irvine, J. Bae, W.Z. Zhou, Electrochemical investigation of composite cathodes with $\mathrm{SmBa}_{0.5} \mathrm{Sr}_{0.5} \mathrm{Co}_{2} \mathrm{O}_{5+\delta}$ cathodes for intermediate temperature-operating solid oxide fuel cell, Chem. Mater. 22 (2010) 883-892.

[13] M. Li, W. Zhou, X. Xu, Z. Zhu, $\mathrm{SrCo}_{0.85} \mathrm{Fe}_{0.1} \mathrm{P}_{0.05} \mathrm{O}_{3-\delta}$ perovskite as a cathode for intermediate-temperature solid oxide fuel cells, J. Mater. Chem. A 1 (2013) 13632-13639.

[14] W. Zhou, F.L. Liang, Z.P. Shao, J.L. Chen, Z.H. Zhu, Heterostructured electrode with concentration gradient shell for highly efficient oxygen reduction at low temperature, Sci. Rep.1 (2011) 1-6.

[15] Y.L. Zhu, Z.-G. Chen, W. Zhou, S.S. Jiang, J. Zou, Z.P. Shao, An A-Site-Deficient Perovskite offers High Activity and Stability for Low-Temperature Solid-Oxide Fuel Cells, ChemSusChem 6 (2013) 2249-2254.

[16] A. Weber, E. Ivers-Tiffée, Materials and concepts for solid oxide fuel cells (SOFCs) in stationary and mobile applications, J. Power Sources 127 (2004) 273-283. [17] F. Riza, C. Ftikos, F. Tietz, W. Fischer, Preparation and characterization of $\operatorname{Ln}_{0.8}$ $\mathrm{Sr}_{0.2} \mathrm{Fe}_{0.8} \mathrm{Co}_{0.2} \mathrm{O}_{3-\mathrm{x}}(\mathrm{Ln}=\mathrm{La}, \mathrm{Pr}, \mathrm{Nd}, \mathrm{Sm}, \mathrm{Eu}, \mathrm{Gd})$. J. Eur. Ceram. Soc. 21 (2001) 1769-1773. 
[18] K. Huang, H.Y. Lee, J.B. Goodenough, Sr-and Ni-doped $\mathrm{LaCoO}_{3}$ and $\mathrm{LaFeO}_{3}$ perovskites new cathode materials for solid-oxide fuel cells, J. Electrochem. Soc. 145 (1998) 3220-3227.

[19] M. Arnold, T.M. Gesing, J. Martynczuk, A. Feldhoff, Correlation of the formation and the decomposition process of the BSCF perovskite at intermediate temperatures, Chem. Mater.20 (2008) 5851-5858.

[20] S. Švarcová, K. Wiik, J. Tolchard, H.J. Bouwmeester, T. Grande, Structural instability of cubic perovskite $\mathrm{Ba}_{\mathrm{x}} \mathrm{Sr}_{1-\mathrm{x}} \mathrm{Co}_{1-\mathrm{y}} \mathrm{Fe}_{\mathrm{y}} \mathrm{O}_{3-\delta}$, Solid State Ionics178 (2008) $1787-1791$.

[21] M. Arnold, Q. Xu, F.D. Tichelaar, A. Feldhoff, Local charge disproportion in a high-performance perovskite, Chem. Mater. 21 (2009) 635-640.

[22] K. Efimov, Q. Xu, A. Feldhoff, Transmission electron microscopy study of $\mathrm{Ba}_{0.5} \mathrm{Sr}_{0.5} \mathrm{Co}_{0.8} \mathrm{Fe}_{0.2} \mathrm{O}_{3-\delta}$ perovskite decomposition at intermediate temperatures, Chem. Mater. 22 (2010) 5866-5875.

[23] W. Zhou, J. Sunarso, J. Motuzas,F.L. Liang, Z.G. Chen, L.Ge, S.M. Liu, A. Julbe, Z.H. Zhu, Deactivation and regeneration of oxygen reduction reactivity on double perovskite $\mathrm{Ba}_{2} \mathrm{Bi}_{0.1} \mathrm{Sc}_{0.2} \mathrm{Co}_{1.7} \mathrm{O}_{6-x}$ cathode for intermediate-temperature solid oxide fuel cells, Chem. Mater. 23(2011) 1618-1624.

[24] G.L. Xiao, Q. Liu, S.W. Wang, V.G. Komvokis, M.D. Amiridis, A. Heyden, S.G. Ma, F.L. Chen, Synthesis and characterization of Mo-doped $\mathrm{SrFeO}_{3-\delta}$ as cathode materials for solid oxide fuel cells. J. Power Sources, 202 (2012) 63-69. 
[25] J.M. Porras-Vazquez, T. Pike, C.A. Hancock, J.F. Marco, F.J. Berry, P.R. Slater, Investigation into the effect of $\mathrm{Si}$ doping on the performance of $\mathrm{SrFeO}_{3-\delta} \mathrm{SOFC}$ electrode materials. J. Mater. Chem. A, 1 (2013) 11834-11841.

[26] Y.J. Niu, W. Zhou, J. Sunarso, L. Ge, Z.H. Zhu, Z.P. Shao, High performance cobalt-free perovskite cathode for intermediate temperature solid oxide fuel cells, J. Mater. Chem. 20 (2010) 9619-9622.

[27] Y.J. Niu, F.L. Liang, W. Zhou, J. Sunarso, Z.H. Zhu, Z.P. Shao, A Three-dimensional highly interconnected composite oxygen reduction reaction electrocatalyst prepared from a core-shell precursor, ChemSusChem 4 (2011) $1582-1586$.

[28] Y.J. Niu, J. Sunarso, W. Zhou, F.L. Liang, L. Ge, Z.H. Zhu, Z.P. Shao, Evaluation and optimization of $\mathrm{Bi}_{1-x} \mathrm{Sr}_{\mathrm{x}} \mathrm{FeO}_{3-\delta}$ perovskites as cathodes of solid oxide fuel cells, Int. J. Hydrogen Energy 36 (2011) 3179-3186.

[29] Y.J. Niu, J. Sunarso, W. Zhou, Z.H. Zhu, Z.P. Shao, A comparative study of oxygen reduction reaction on $\mathrm{Bi}$-and $\mathrm{La}$-doped $\mathrm{SrFeO}_{3-\delta}$ perovskite cathodes, $\mathrm{J}$. Electrochem.Soc.158(2011)B132-B138.

[30] Y.J. Niu, J. Sunarso, W. Zhou, F.L. Liang,Z.H. Zhu, Z.P. Shao,A single-step synthesized cobalt-free barium ferrites-based composite cathode for intermediate temperature solid oxide fuel cells, Electrochem. Commun. 13(2011) 1340-1343.

[31] S.S. Jiang, W. Zhou, Y.J. Niu, Z.H. Zhu, Z.P. Shao, Phase transition of a cobalt free perovskite as a high performance cathode for intermediate temperature solid oxide fuel cells, ChemSusChem 5(2012) 2023-2031. 
[32] S.S. Jiang, W. Zhou, F.L. Liang, Z.P. Shao, Hierarchical porous cobalt-free perovskite electrode for highly efficient oxygen reduction, J. Mater. Chem. 22(2012) $16214-16218$.

[33] R.D. Shannon, C.T. Prewitt, Effective ionic radii in oxides and fluorides, Acta Cryst. B25 (1969) 925-946.

[34] S. Hou, J.A. Alonso, J.B. Goodenough, Co-free, iron perovskites as cathode materials for intermediate-temperature solid oxide fuel cells. J. Power Sources 195 (2010) 280-284.

[35] Y.L. Zhu, J. Sunarso, W. Zhou, S.S. Jiang, Z.P. Shao, High-performance $\mathrm{SrNb}_{0.1} \mathrm{Co}_{0.9-\mathrm{x}} \mathrm{Fe}_{\mathrm{x}} \mathrm{O}_{3-\delta}$ perovskite cathodes for low-temperature solid oxide fuel cells, J. Mater. Chem. A 2 (2014) 15454-15462.

[36] F.F. Dong, D.J. Chen, R. Ran, H. Park, C. Kwak, Z.P. Shao, A comparative study of $\mathrm{Sm}_{0.5} \mathrm{Sr}_{0.5} \mathrm{MO}_{3-\delta}(\mathrm{M}=\mathrm{Co}$ and $\mathrm{Mn})$ as oxygen reduction electrodes for solid oxide fuel cells, Inter. J. Hydrogen Energy 37 (2012) 4377-4387.

[37] F.F. Dong, D.J. Chen, Y.B. Chen, Q. Zhao, Z.P. Shao, La-doped $\mathrm{BaFeO}_{3-\delta}$ perovskite as a cobalt-free oxygen reduction electrode for solid oxide fuel cells with oxygen-ion conducting electrolyte, J. Mater. Chem.22 (2012) 15071-15079.

[38] M. Li, Y. Wang, Y.L. Wang, F.L. Chen, C.R. Xia, Bismuth doped lanthanum ferrite perovskites as novel cathodes for intermediate-temperature solid oxide fuel cells, ACS Appl. Mater. Inter. 6 (2014)11286-11294. 
[39] B.M. Qian, Y.B. Chen, M.O. Tade, Z.P. Shao, $\mathrm{BaCo}_{0.6} \mathrm{Fe}_{0.3} \mathrm{Sn}_{0.1} \mathrm{O}_{3-\delta}$ perovskite as a new superior oxygen reduction electrode for intermediate-to-low temperature solid oxide fuel cells, J. Mater. Chem. A 2 (2014) 15078-15086.

[40] M. Kuhn, Oxygen nonstoichiometry and defect chemistry of perovskitestructured $\mathrm{Ba}_{\mathrm{x}} \mathrm{Sr}_{1-\mathrm{x}} \mathrm{Ti}_{1-\mathrm{y}} \mathrm{Fe}_{\mathrm{y}} \mathrm{O}_{3-\mathrm{y} /(2+\delta)}$ solid solutions. Chem. Mater. 25 (2013) 2970-2975. 


\section{Figure captions}

Fig. 1. Room temperature powder $\mathrm{x}$-ray diffraction patterns of $\operatorname{SNFx}(\mathrm{x}=0.05,0.1,0.2)$ powders (a). The magnified diffraction peak at $2 \theta=31.5-34 \cdot 0^{\circ}(\mathrm{b})$.

Fig. 2. Mössbauer spectra of SNFx, $x=0.05$ (a), $x=0.1$ (b), $x=0.2$ (c).

Fig. 3. Thermal expansion behavior of $\operatorname{SNFx}(x=0.05,0.1,0.2)$ (a). Oxygen temperature programmed desorption results for $\mathrm{SNFx}$ powders $(\mathrm{x}=0.05,0.1,0.2)(\mathrm{b})$.

Fig. 4. The oxygen nonstoichiometry $(\delta)$ of $\operatorname{SNFx}(x=0.05,0.1,0.2)$ between 550 and $750{ }^{\circ} \mathrm{C}$. Insert graph show the TGA curves of SNFx between 350 to $800{ }^{\circ} \mathrm{C}$ (a). The average valence state of iron (n) in $\operatorname{SNFx}(x=0.05,0.1,0.2)$ between 550 and $750{ }^{\circ} \mathrm{C}$ (b).

Fig. 5. The Arrhenius plots of area specific resistances (ASRs) and activation energies $\left(E_{a}\right)$ of $\operatorname{SNFx}(\mathrm{x}=0.05,0.1,0.2)$ cathodes between 550 and $750{ }^{\circ} \mathrm{C}$.

Fig. 6. Scanning electron microscopy images of the cross-section of SNFx $(x=0.05$, $0.1,0.2)$ cathodes fired at $1000^{\circ} \mathrm{C}$ for $2 \mathrm{~h}$ in air.

Fig. 7. Electrical conductivities of $\operatorname{SNFx}(x=0.05,0.1,0.2)$ between 300 and $900{ }^{\circ} \mathrm{C}$.

Fig. 8. I-V and I-P plots of the single SOFCs with $\mathrm{SrFeO}_{3-\delta}$ (a), SNF0.05 (b), SNF0.1 (c) and SNF0.2 (d) recorded from 550 to $700{ }^{\circ} \mathrm{C}$. The peak power densities of SNFx $(\mathrm{x}=0,0.05,0.1,0.2)$ at various temperatures $(\mathrm{e})$. 


\section{Tables}

Table 1 The concentrations of strontium, niobium and iron ions in the SNFx $(x=0.05$, $0.1,0.2)$ powders.

\begin{tabular}{|c|c|c|c|c|}
\hline \multirow[t]{2}{*}{ Sample } & \multicolumn{3}{|c|}{ Concentrations of metal ions $\left(\mathrm{mg} \mathrm{L}^{-1}\right)$} & Molar ratio \\
\hline & $\mathrm{Sr}$ & $\mathrm{Nb}$ & $\mathrm{Fe}$ & $\mathrm{Sr}: \mathrm{Nb}: \mathrm{Fe}$ \\
\hline SNF0.05 & 11.720 & 0.598 & 7.126 & $1.0: 0.048: 0.95$ \\
\hline SNF0.1 & 13.292 & 1.401 & 7.633 & $1.0: 0.099: 0.90$ \\
\hline SNF0.2 & 9.600 & 2.015 & 4.907 & $1.0: 0.20: 0.80$ \\
\hline
\end{tabular}


Table 2 Room temperature structure parameters of $\operatorname{SNFx}(x=0,0.05,0.1,0.2)$ perovskites.

\begin{tabular}{|c|c|c|c|c|}
\hline & $\mathrm{SF}^{*}$ & SNF0.05 & SNF0.1 & SNF0.2 \\
\hline Space group & $\mathrm{I} 4 / \mathrm{mmm}$ & $\mathrm{Pm} 3 \mathrm{~m}$ & $\mathrm{P} 4 \mathrm{~mm}$ & $\mathrm{P} 4 \mathrm{~mm}$ \\
\hline $\mathrm{a}(\AA)$ & $10.9235(1)$ & $3.875727(6)$ & $3.895433(7)$ & $3.909028(3)$ \\
\hline $\mathrm{b}(\AA)$ & - & $3.875727(6)$ & $3.895433(7)$ & $3.909028(3)$ \\
\hline $\mathrm{c}(\AA)$ & $7.6965(1)$ & $3.875727(6)$ & $3.889986(5)$ & $3.911850(1)$ \\
\hline$V\left(\AA^{3}\right)$ & $57.40(1)$ & $58.2183(3)$ & $59.0282(2)$ & $59.7750(3)$ \\
\hline$\chi^{2}$ & - & 1.14 & 0.99 & 1.32 \\
\hline Rwp (\%) & 3.43 & 7.69 & 6.94 & 5.34 \\
\hline $\mathrm{Rp}(\%)$ & - & 6.14 & 5.49 & 3.95 \\
\hline${ }^{\mathrm{a}} \mathrm{SF} *$ Ref. [25] & & & & \\
\hline
\end{tabular}


Table 3 Parameters obtained from the Mössbauer spectroscopy of the SNFx oxides

\begin{tabular}{llllc}
\hline Compositions & Iron valence & IS. mm/s & QS. mm/s & I.\% \\
\hline SNF0.05 & +3 & 0.350 & 0.419 & 59.7 \\
& +4 & -0.143 & & 40.3 \\
SNF0.1 & +3 & 0.349 & 0.411 & 62.5 \\
& +4 & & & 37.5 \\
SNF0.2 & & & & \\
& +3 & 0.126 & & \\
& & & & \\
& +4 & -0.191 & & 29.1 \\
\hline
\end{tabular}


Table 4 The average valence of Fe and oxygen nonstoichiometry calculated from the Mössbauer spectroscopy correspond to RT.

\begin{tabular}{llll}
\hline & SNF0.05 & SNF0.1 & SNF0.2 \\
\hline $\mathrm{n}$ & 3.403 & 3.375 & 3.291 \\
$\delta$ & 0.259 & 0.231 & 0.184 \\
\hline
\end{tabular}


Table 5 The TECs value of SNFx samples at selected temperature ranges

\begin{tabular}{cccc}
\hline Temperature $\left({ }^{\circ} \mathrm{C}\right)$ & & TEC $\left(\times 10^{-6} \mathrm{~K}^{-1}\right)$ & \\
& SNF0.05 & SNF0.1 & SNF0.2 \\
\hline RT-410 & 18.5 & 15.6 & 15.6 \\
$410-1000$ & 32.8 & 27.5 & 24.2 \\
RT-1000 & & & \\
\hline
\end{tabular}


Figure 1a

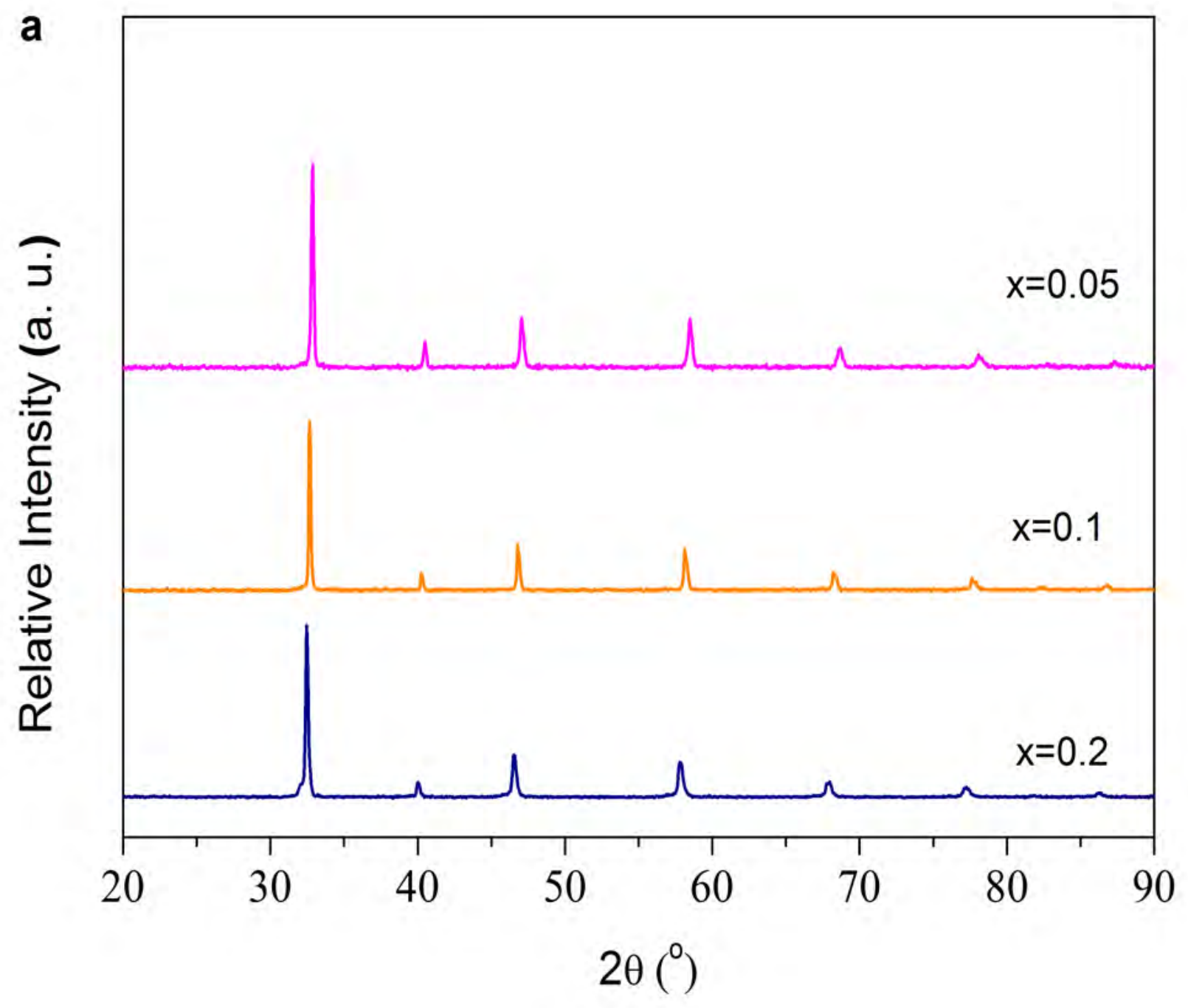


Figure $1 b$

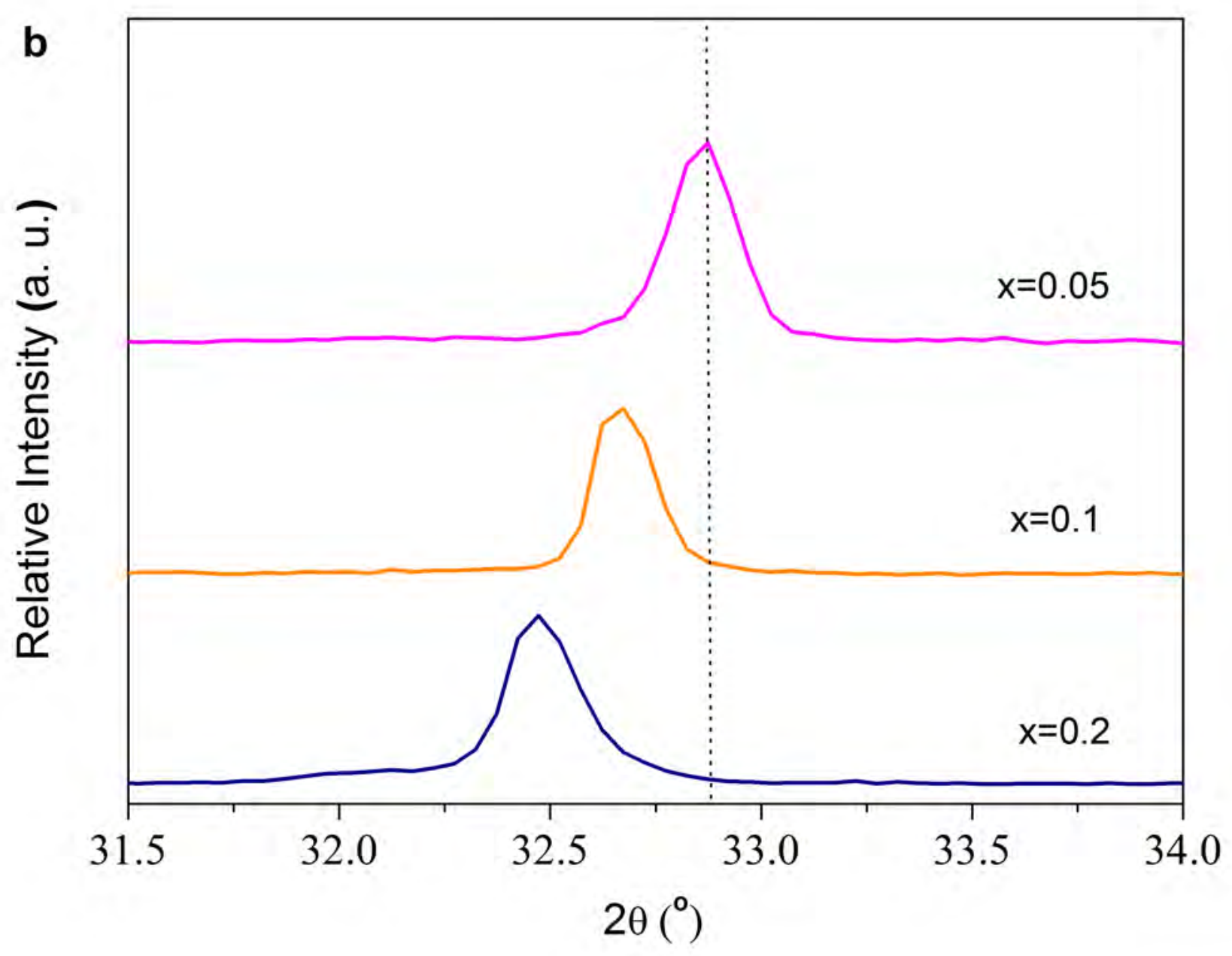


Figure $2 a$

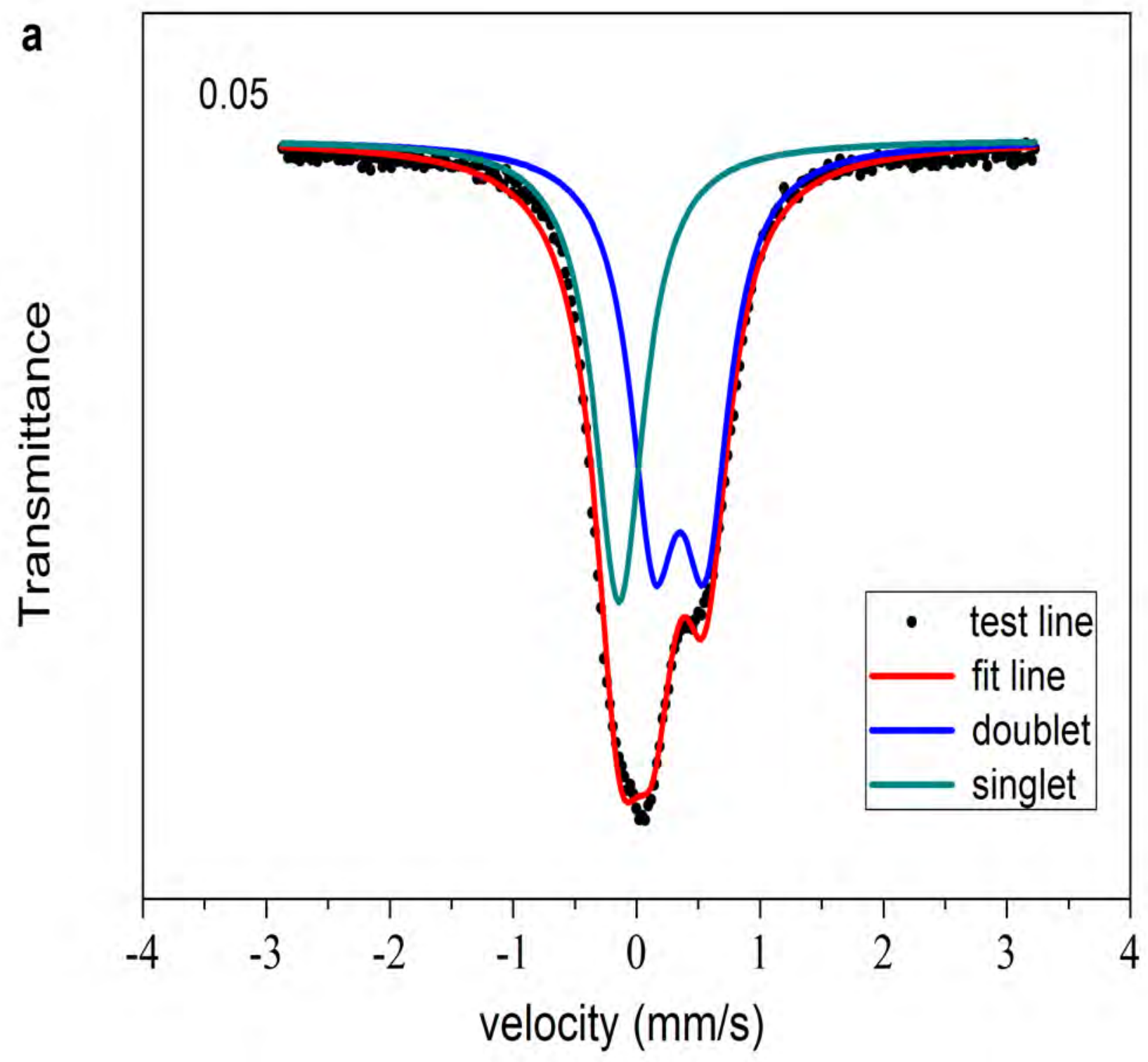


Figure 2b

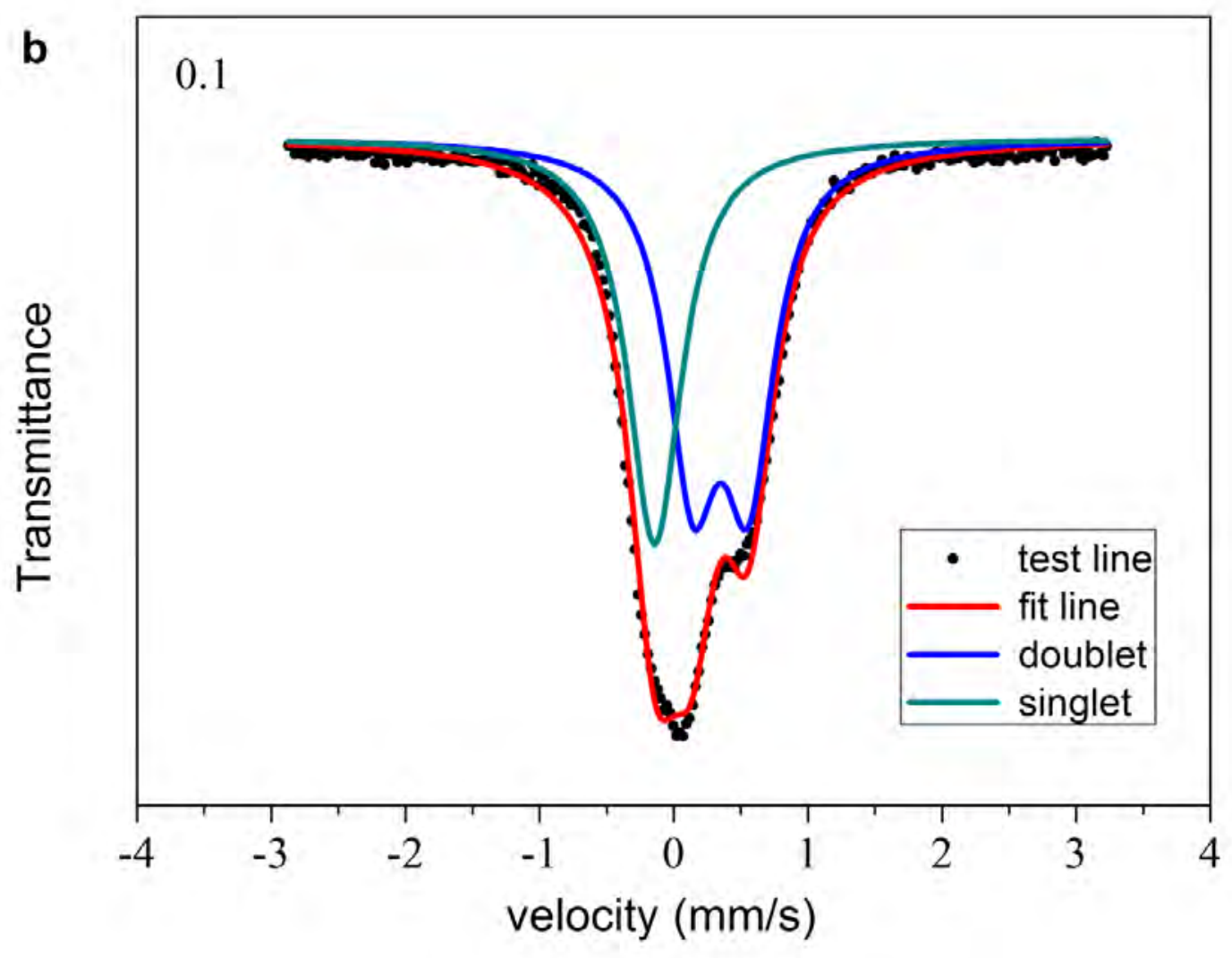


Figure 2c

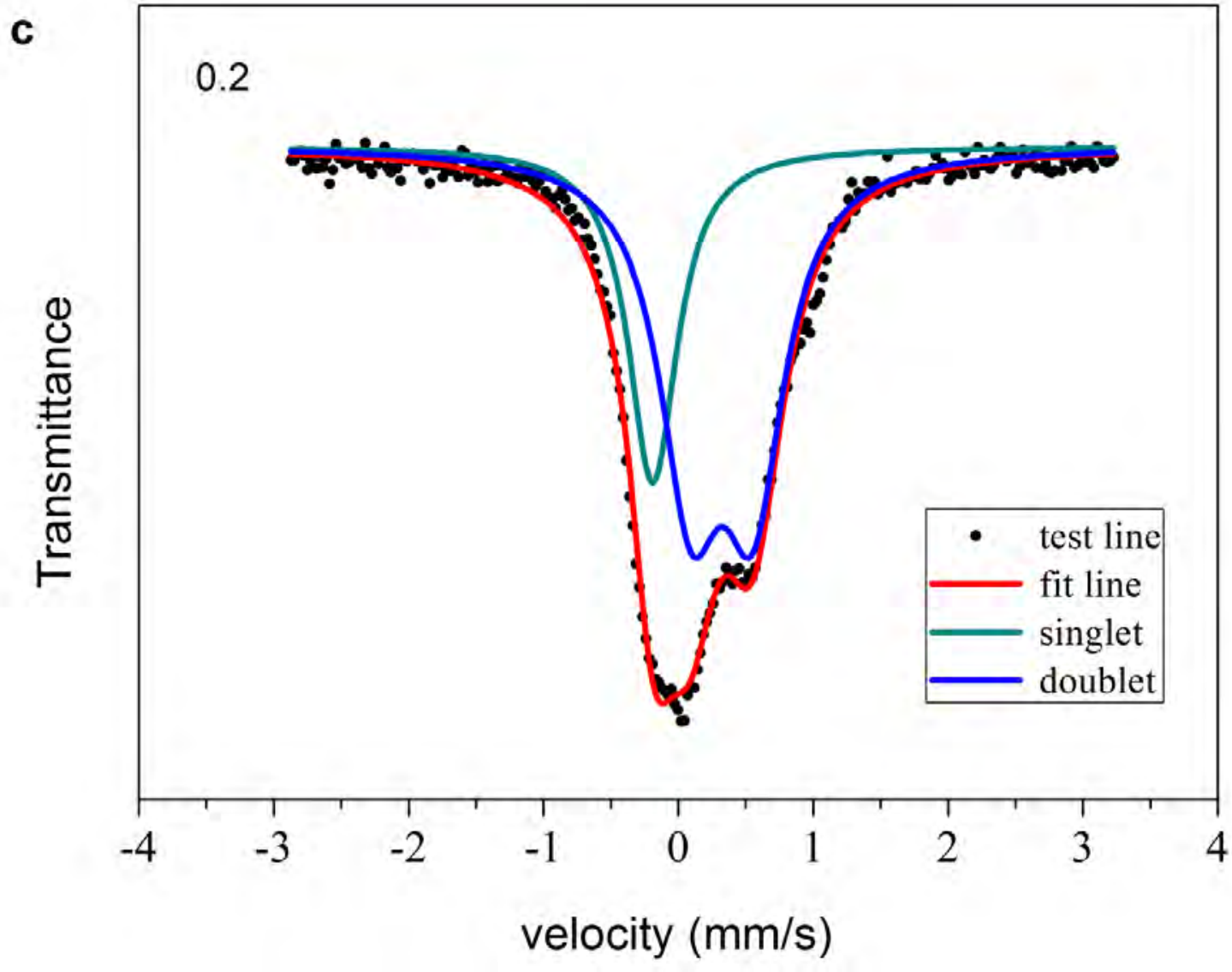


Figure $3 a$

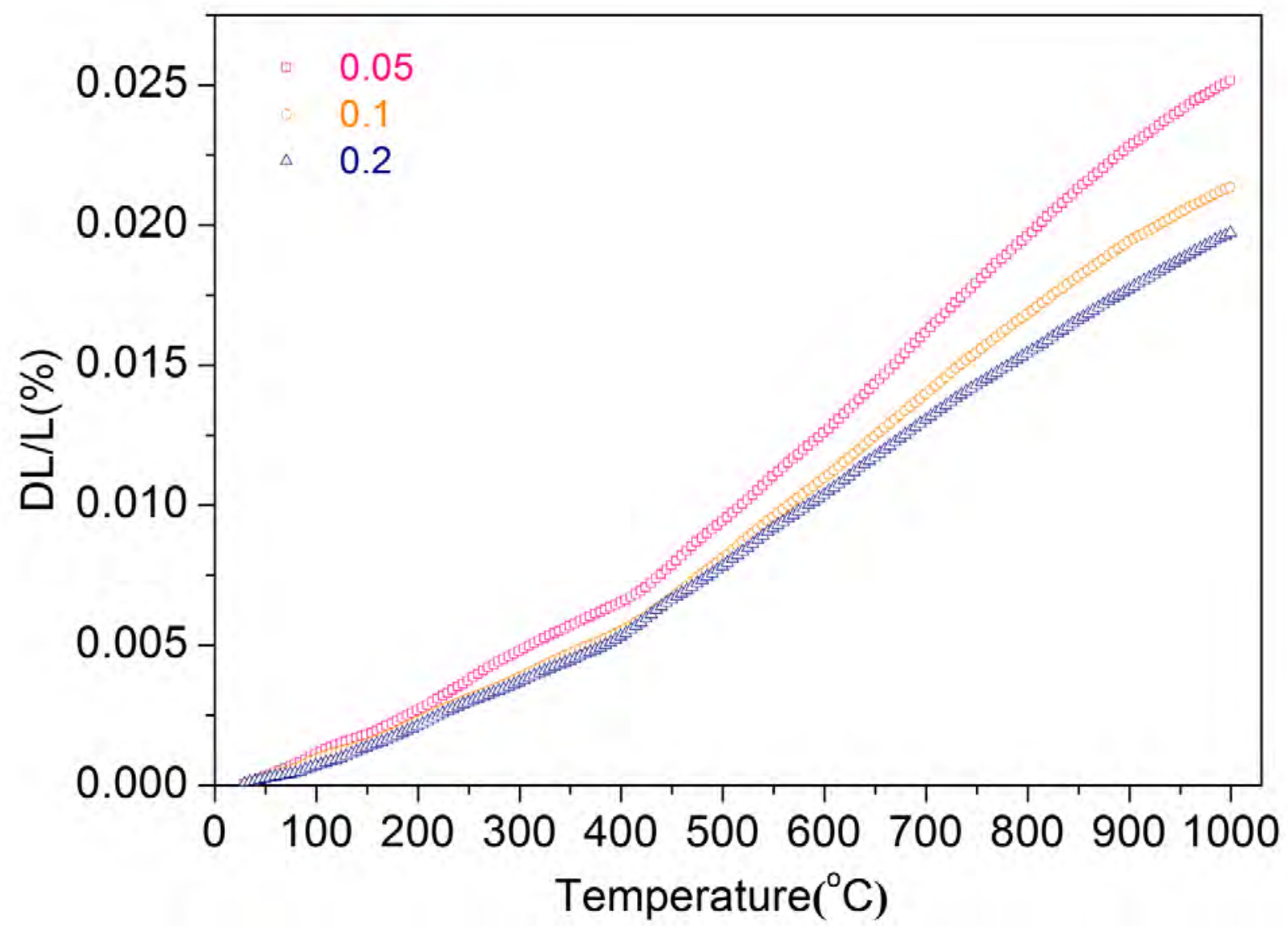


Figure $3 b$

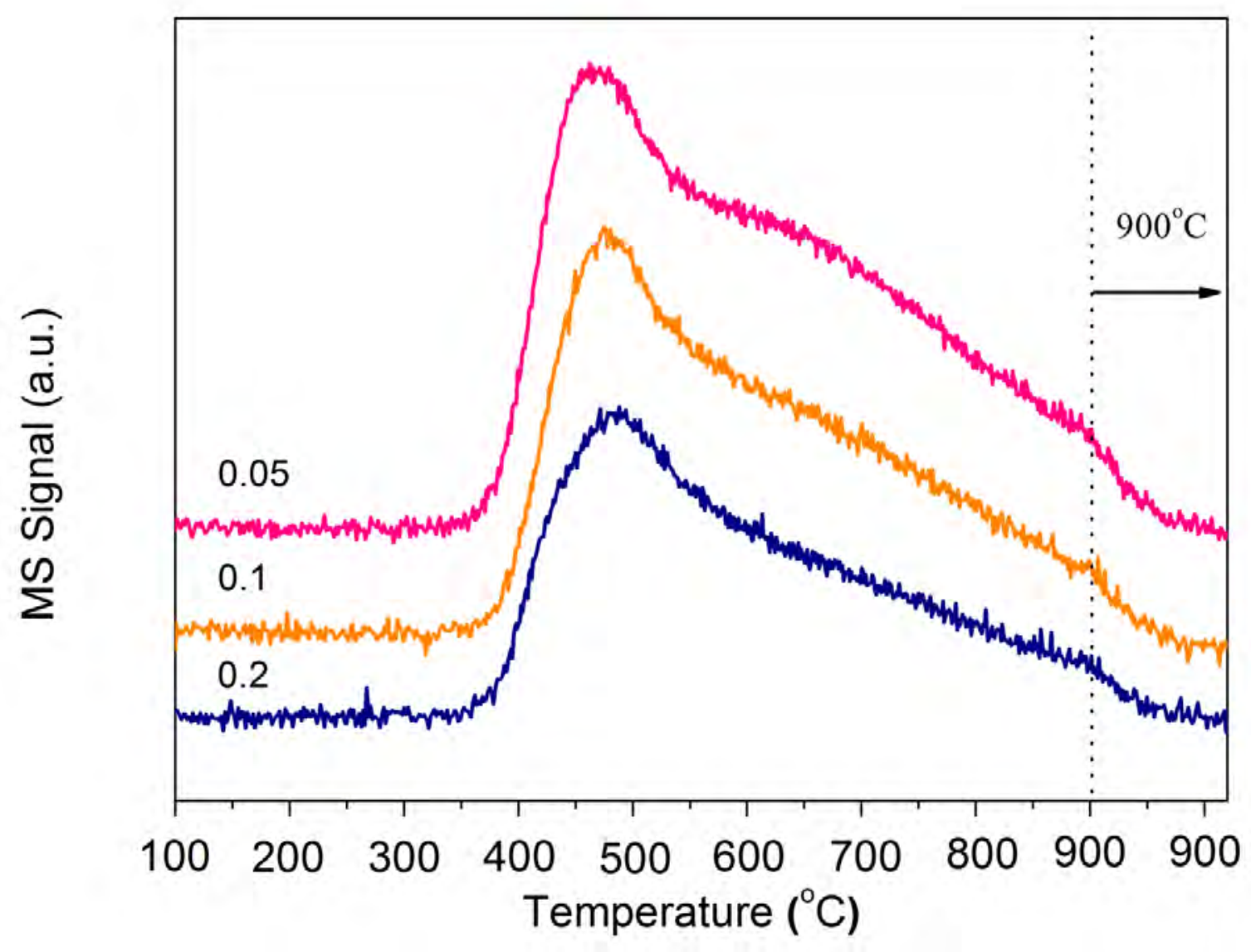


Figure 4a

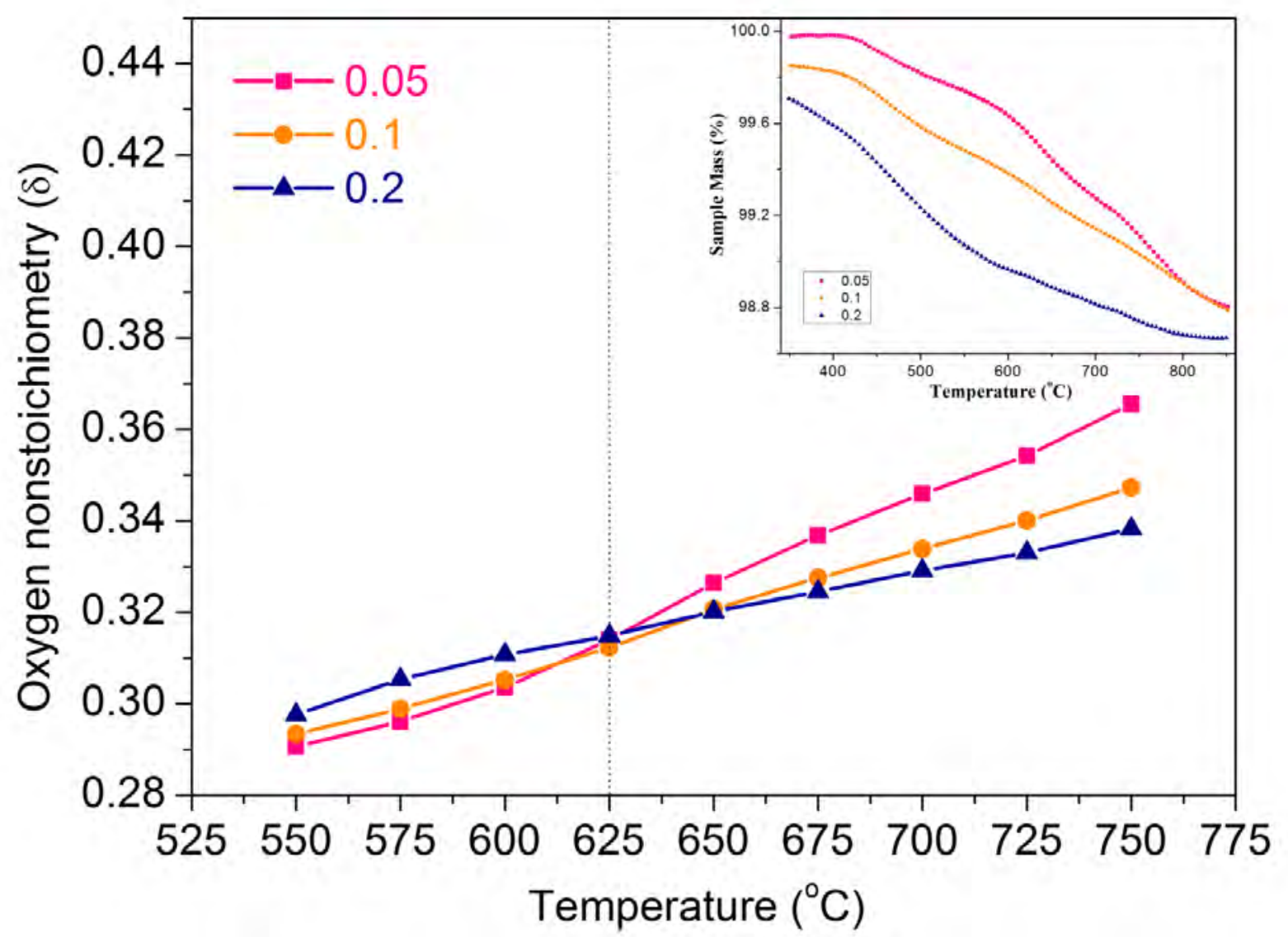


Figure 4b

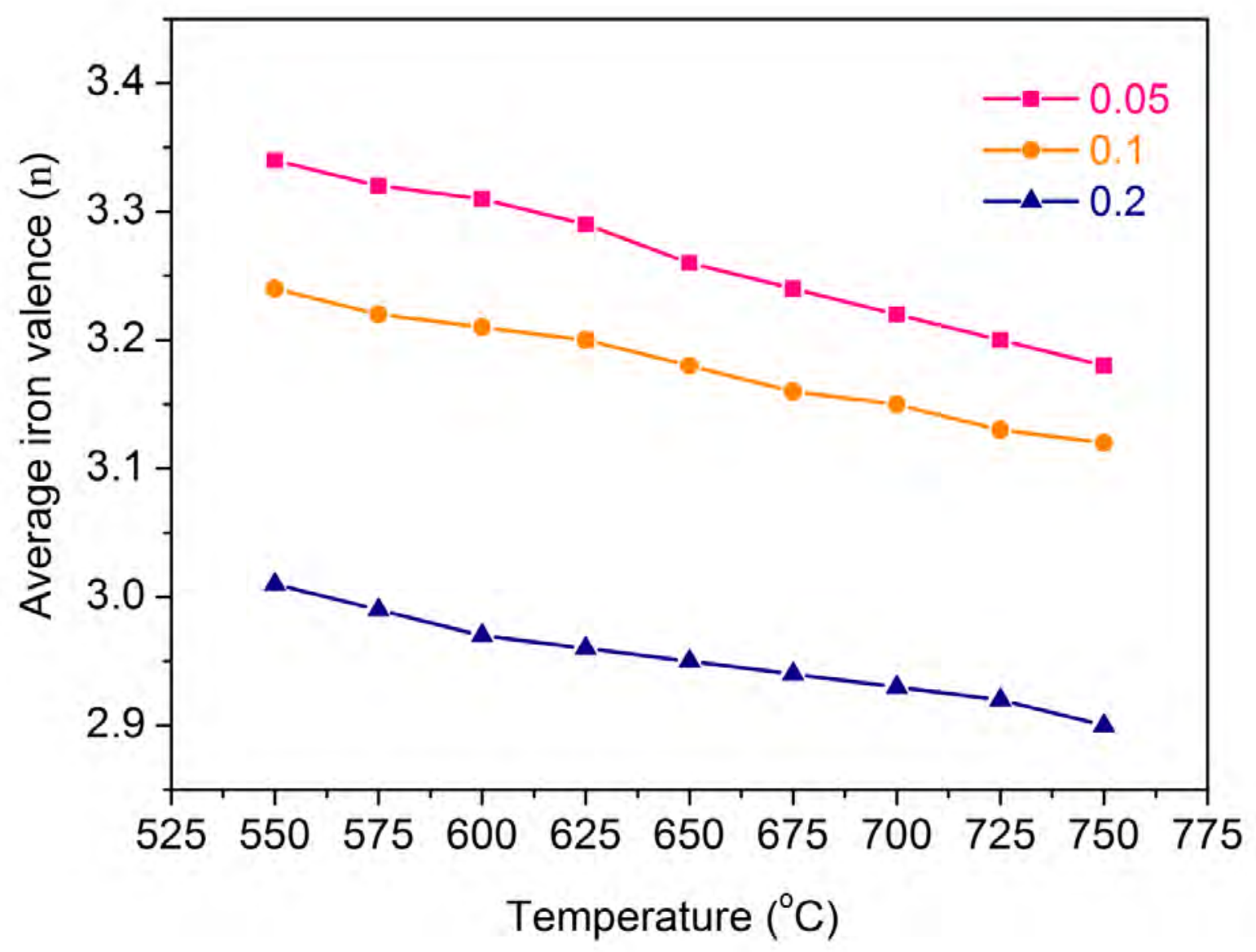


Figure 5

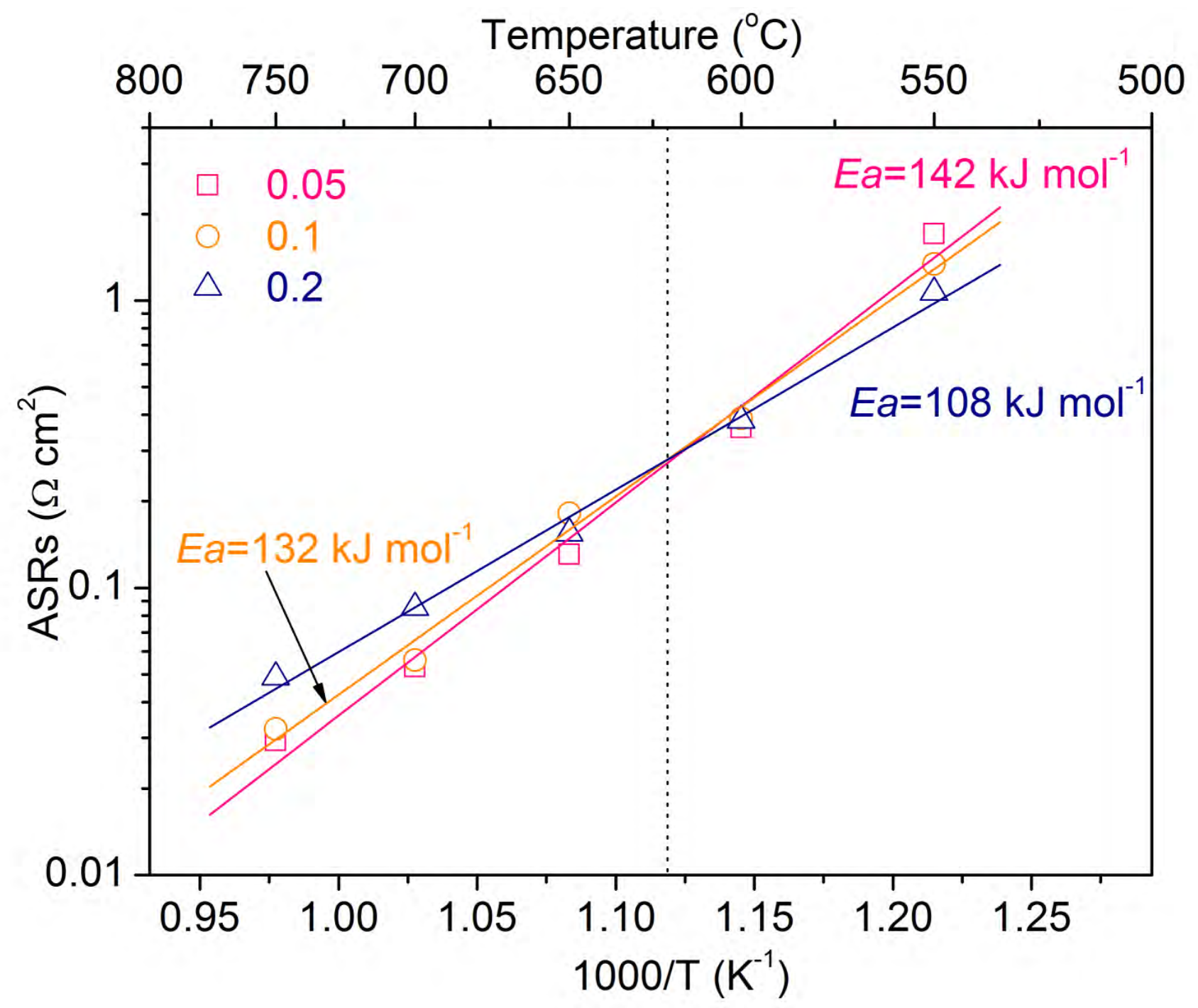


Figure 6

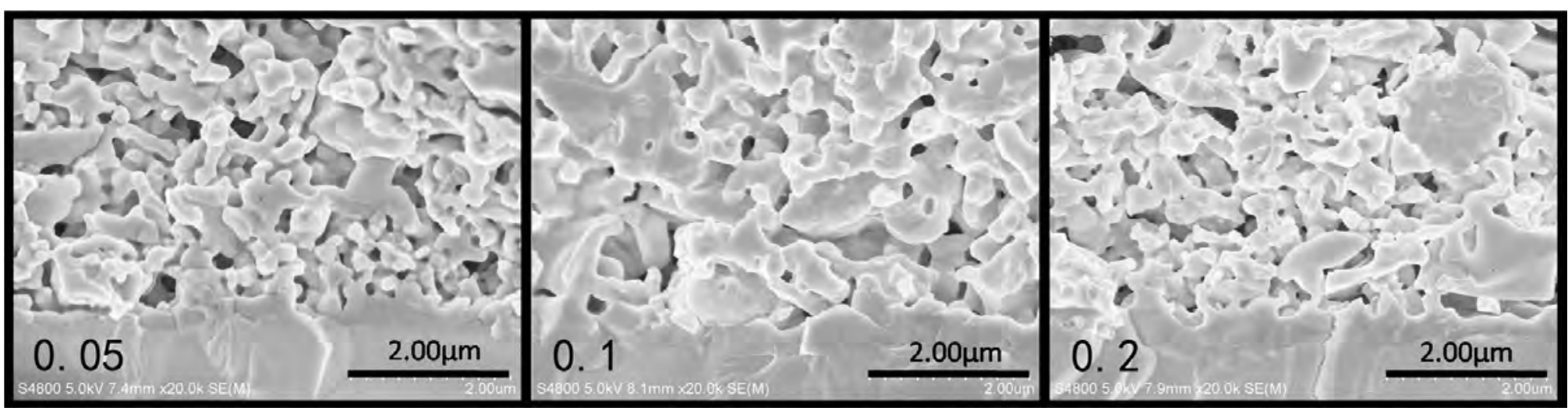


Figure 7

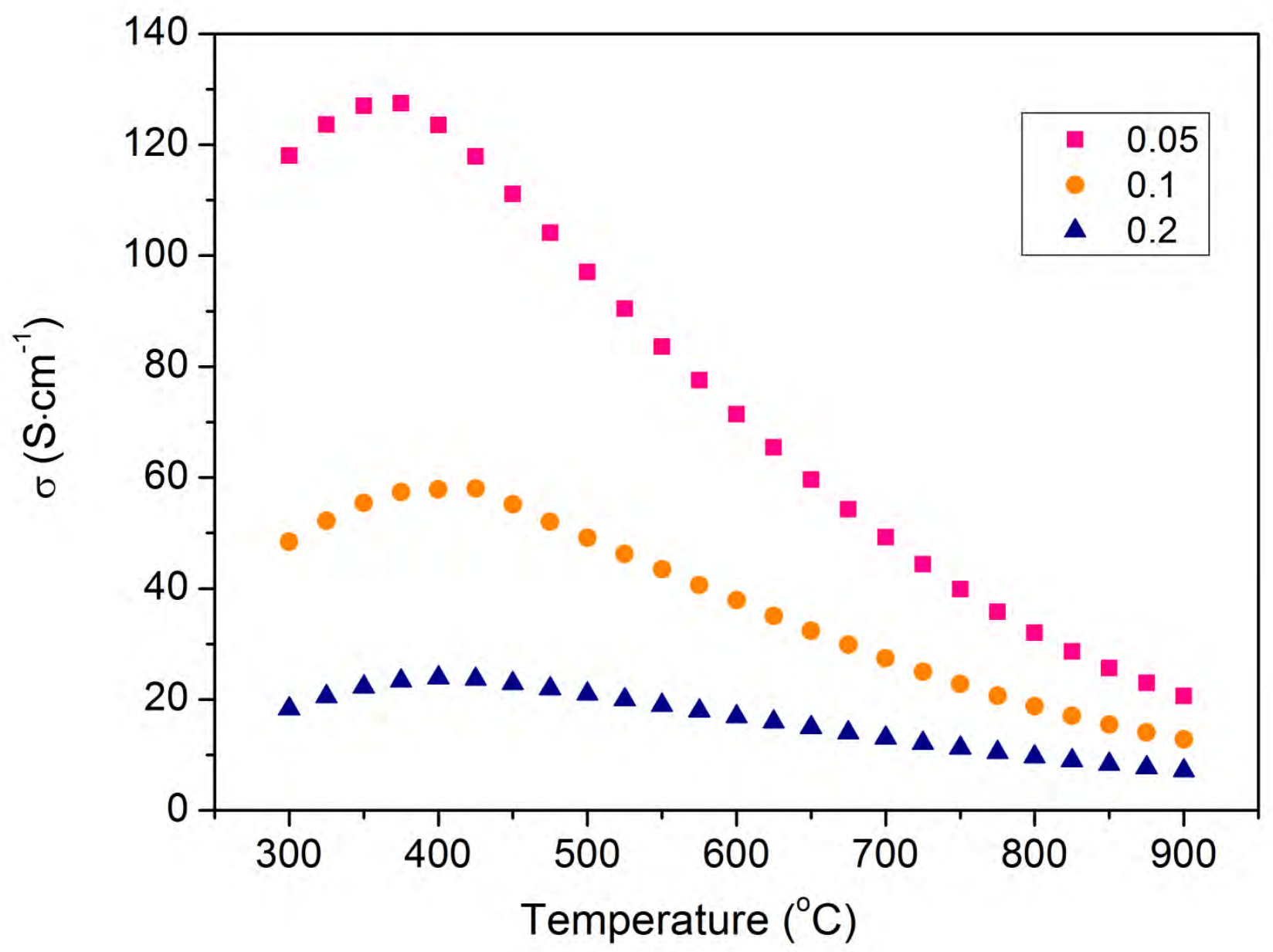


Figure $8 a$

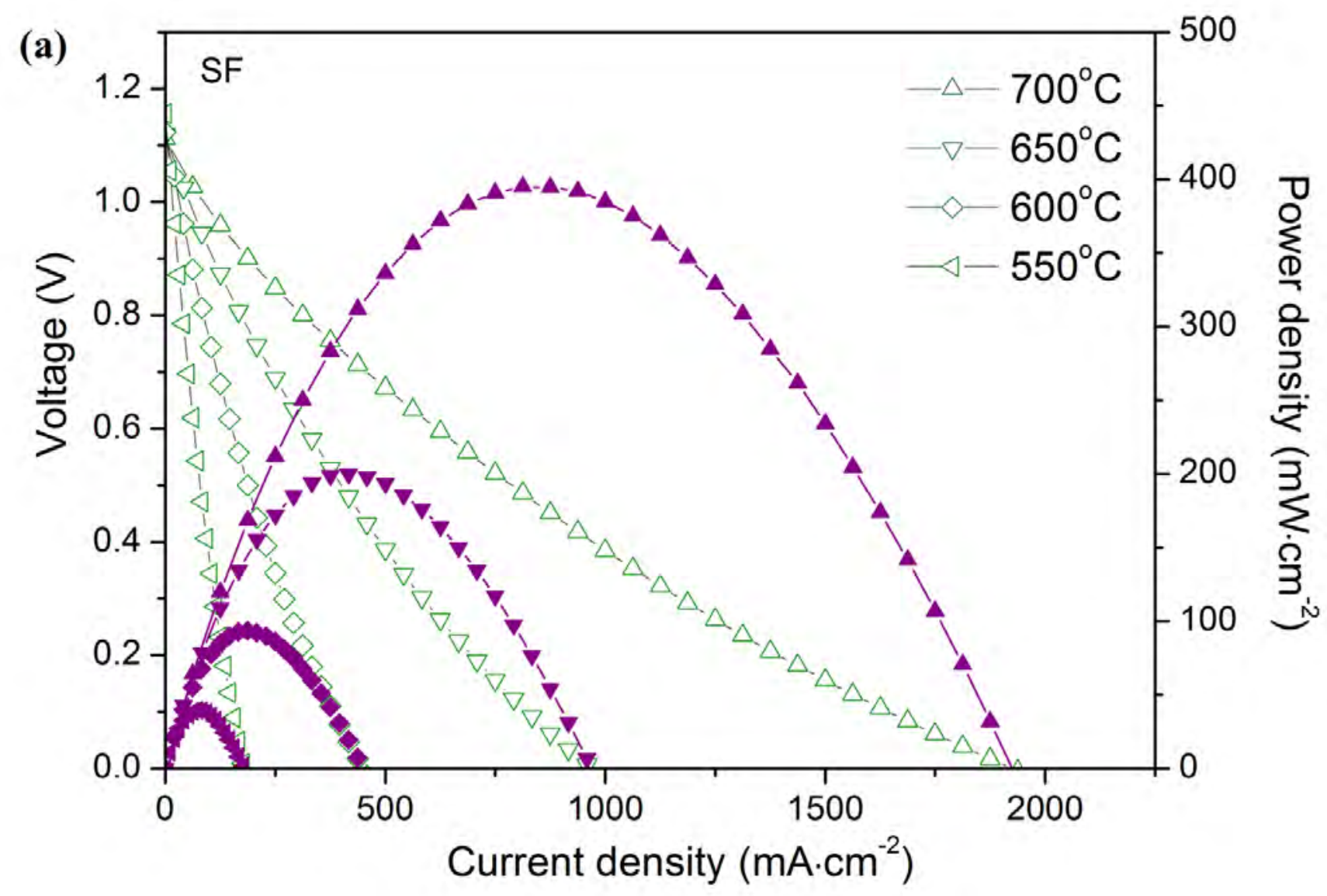


Figure $8 b$

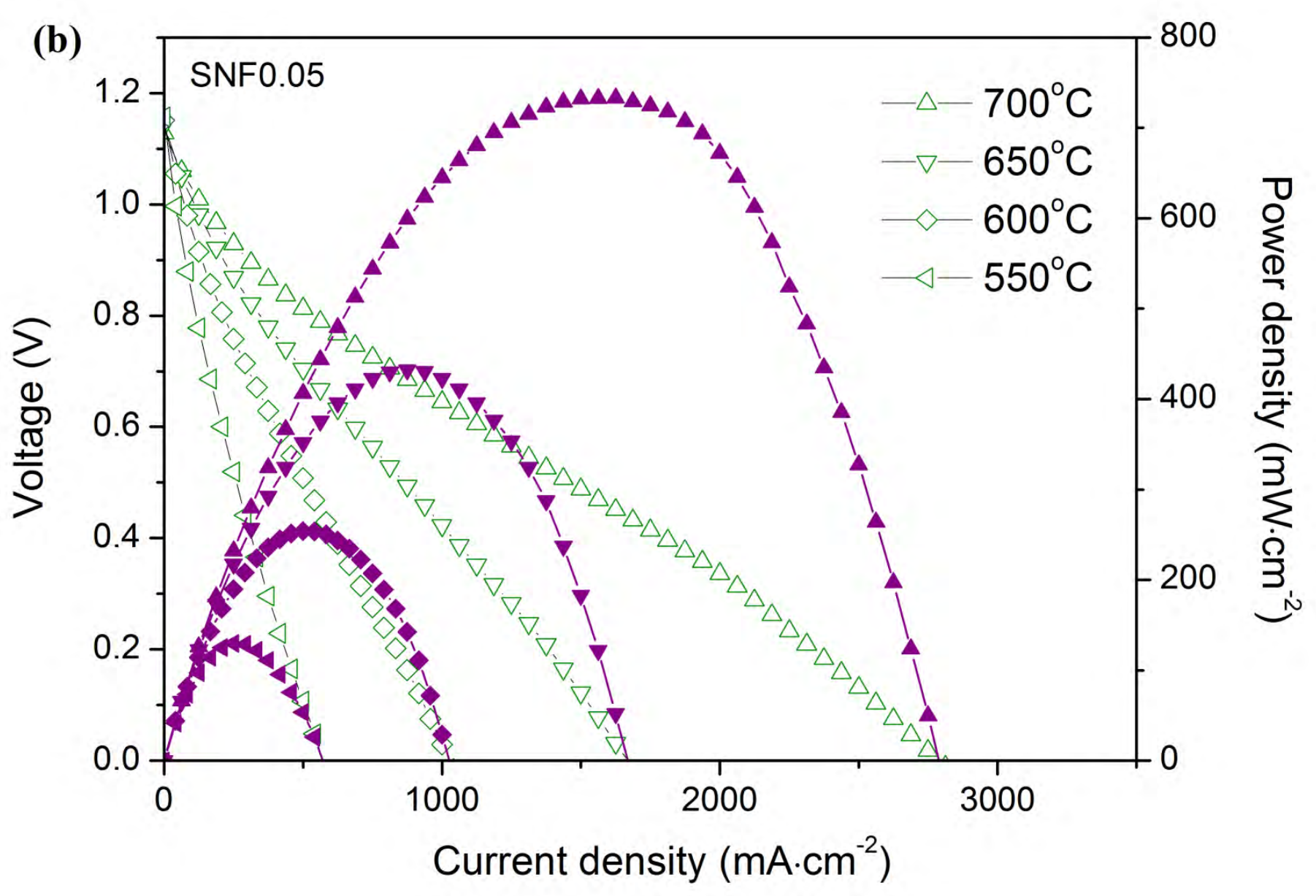


Figure $8 c$

(c)

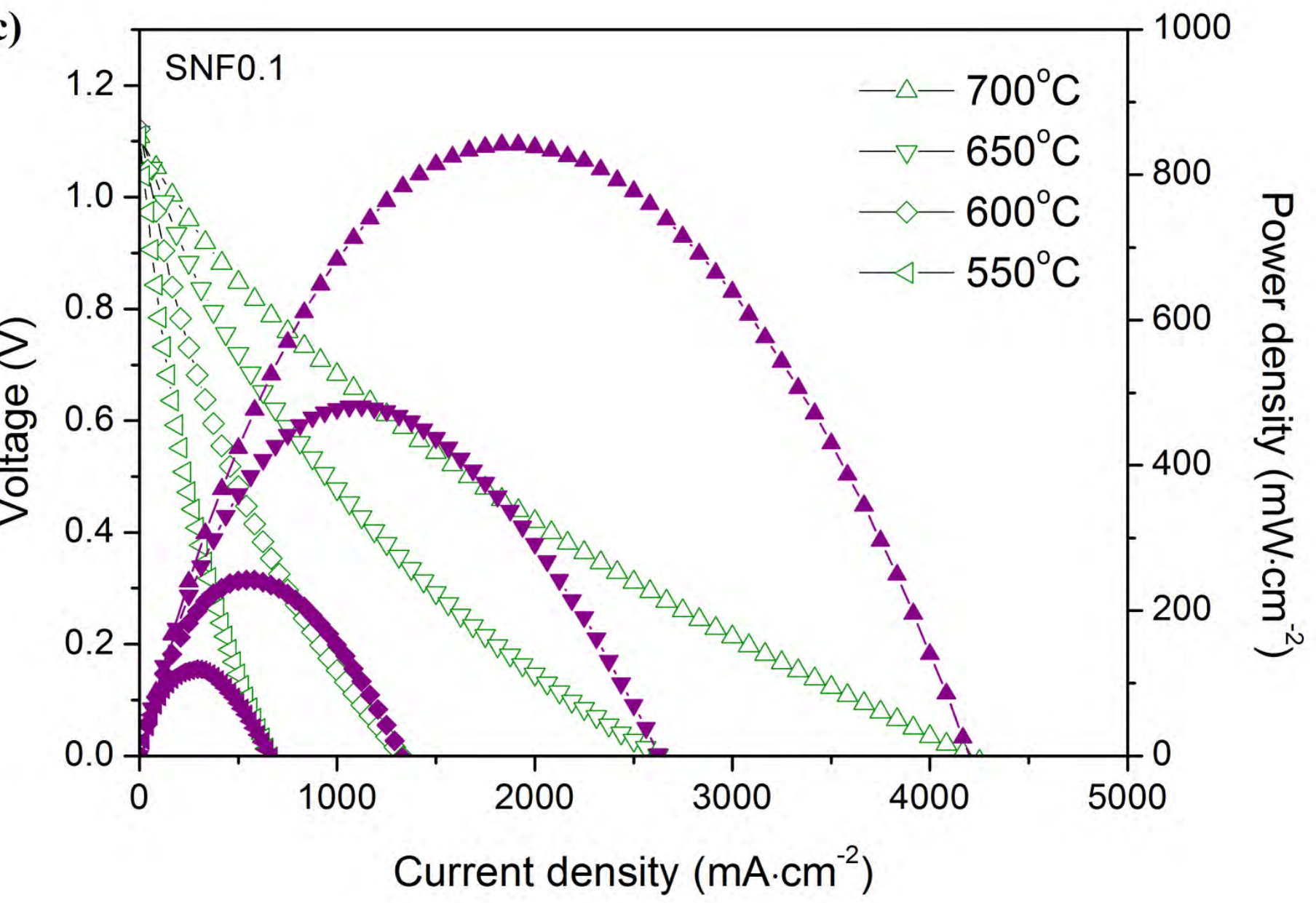


Figure 8d

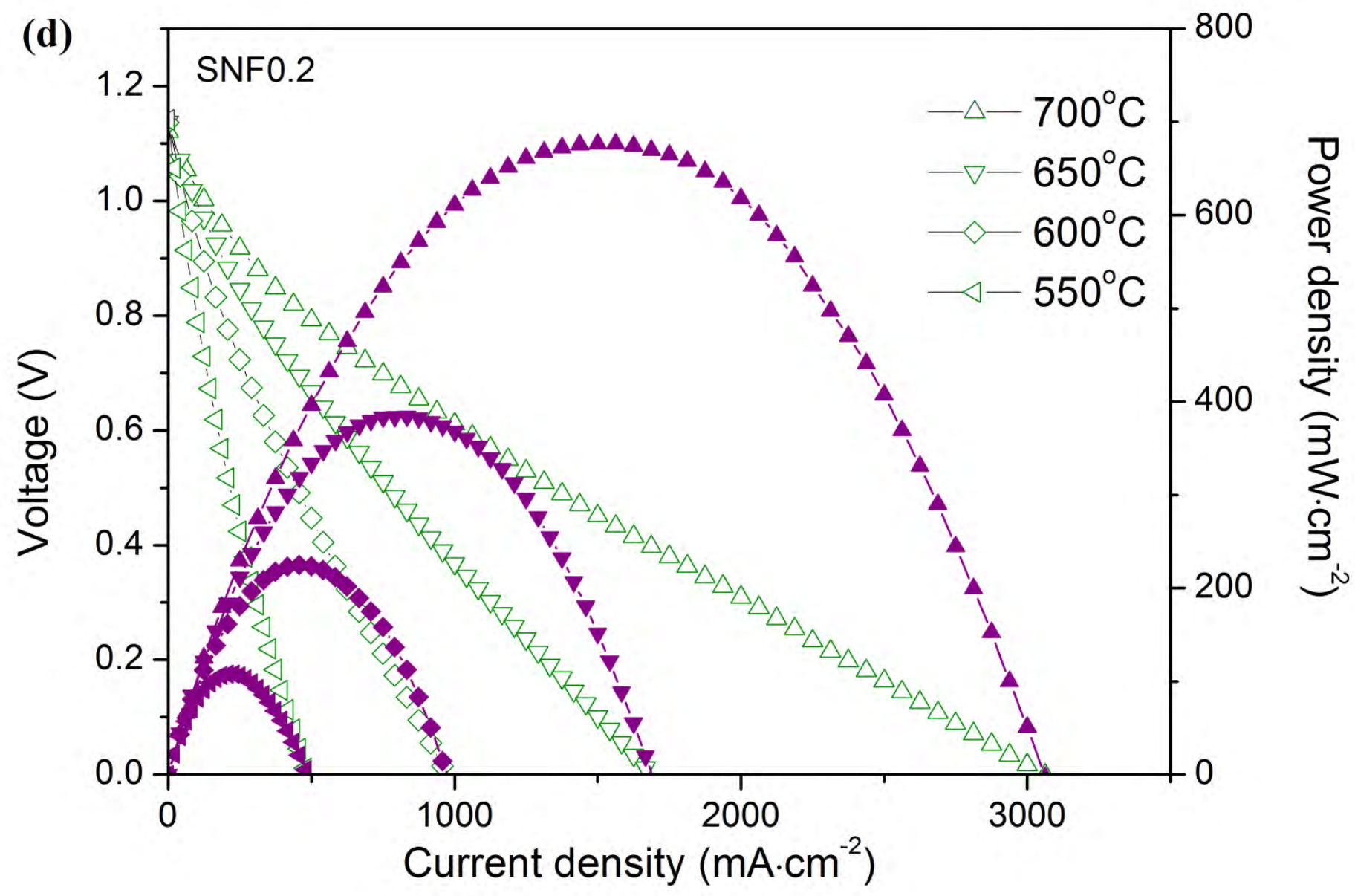


Figure 8e

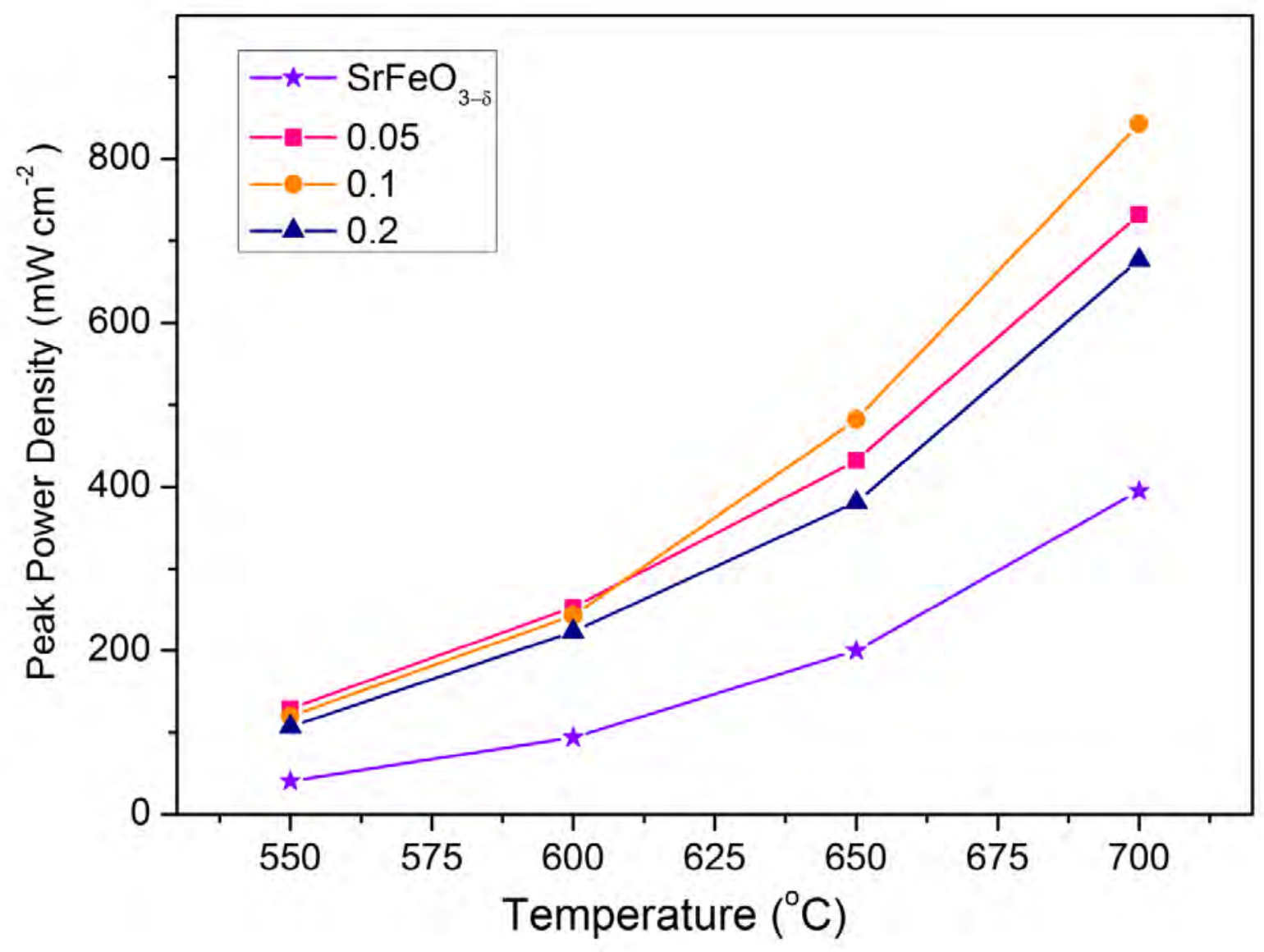

